\title{
Synthesis of Mixed Cu/Ce Oxide Nanoparticles by the Oil-in-Water Microemulsion Reaction Method
}

\author{
Kelly Pemartin-Biernath ${ }^{1,2}$, Andrea V. Vela-González ${ }^{3}$, Maira B. Moreno-Trejo ${ }^{3}$, \\ César Leyva-Porras ${ }^{3}$, Iván E. Castañeda-Reyna ${ }^{4}$, Isaías Juárez-Ramírez ${ }^{4}$, Conxita Solans ${ }^{1}$ and \\ Margarita Sánchez-Domínguez ${ }^{3, *}$ \\ 1 Institut de Química Avançada de Catalunya (IQAC-CSIC) y CIBER en Biotecnología, Biomateriales y \\ Nanomedicina (Ciber-BBN), Jordi Girona 18-26, Barcelona 08034, Spain; kelly.pemartin@gmail.com or \\ kelly.pemartin@mcbride.eu (K.P.-B.); conxita.solans@iqac.csic.es (C.S.) \\ 2 Mc Bride Chemolux S.A.R.L, Rue de I'Industrie, Foetz 3895, Luxembourg \\ 3 Centro de Investigación en Materiales Avanzados, S. C. (CIMAV), Unidad Monterrey, Alianza Norte 202, \\ Parque de Investigación e Innovación Tecnológica, Apodaca 66628, Mexico; \\ andrea.vela@cimav.edu.mx (A.V.V.-G.); maira.moreno@cimav.edu.mx (M.B.M.-T.); \\ cesar.leyva@cimav.edu.mx (C.L.-P.) \\ 4 Universidad Autónoma de Nuevo León, Facultad de Ingeniería Civil, Departamento de Ecomateriales y \\ Energía. Cd. Universitaria, San Nicolás de los Garza 66455, Mexico; fime.iecr@live.com.mx (I.E.C.-R.); \\ isaias.juarezrm@uanl.edu.mx (I.J.-R.) \\ * Correspondence: margarita.sanchez@cimav.edu.mx; Tel.: +52-811-156-0830
}

Academic Editors: Andrea P. Reverberi and Marco Salerno

Received: 25 April 2016; Accepted: 10 June 2016; Published: 16 June 2016

\begin{abstract}
Cerium oxide and mixed $\mathrm{Cu} / \mathrm{Ce}$ oxide nanoparticles were prepared by the oil-in-water $(\mathrm{O} / \mathrm{W})$ microemulsion reaction method in mild conditions. The $\mathrm{Cu} / \mathrm{Ce}$ molar ratio was varied between $0 / 100$ and 50/50. According to X-ray diffraction (XRD), below 30/70 Cu/Ce molar ratio, the materials presented a single phase consistent with cubic fluorite $\mathrm{CeO}_{2}$. However, above $\mathrm{Cu} / \mathrm{Ce}$ molar ratio 30/70, an excess monoclinic $\mathrm{CuO}$ phase in coexistence with the predominant $\mathrm{Cu} / \mathrm{Ce}$ mixed oxide was detected by XRD and High-Resolution Transmission Electron Microscopy (HRTEM). Raman spectroscopy showed that oxygen vacancies increased significantly as the Cu content was increased. Band gap $\left(E_{\mathrm{g}}\right)$ was investigated as a function of the $\mathrm{Cu} / \mathrm{Ce}$ molar ratio, resulting in values from $2.91 \mathrm{eV}$ for $\mathrm{CeO}_{2}$ to $2.32 \mathrm{eV}$ for the mixed oxide with $30 / 70 \mathrm{Cu} / \mathrm{Ce}$ molar ratio. These results indicate that below $30 / 70 \mathrm{Cu} / \mathrm{Ce}$ molar ratio, $\mathrm{Cu}^{2+}$ is at least partially incorporated into the ceria lattice and very well dispersed in general. In addition, the photodegradation of Indigo Carmine dye under visible light irradiation was explored for selected samples; it was shown that these materials can remove such contaminants, either by adsorption and/or photodegradation. The results obtained will encourage investigation into the optical and photocatalytic properties of these mixed oxides, for widening their potential applications.
\end{abstract}

Keywords: mixed oxide nanoparticles; microemulsion; nanoreactor; $\mathrm{CeO}_{2} \mathrm{NPs}$; $\mathrm{CuO}$ NPs

\section{Introduction}

Ceria and ceria-based nanomaterials are well known for their efficiency in numerous applications, such as solid-state electrolytes for electrochemical devices [1], ultraviolet absorbents for sunscreens [2], oxygen storage [3], hybrid solar cells [4], and luminescent materials for violet/blue fluorescence [5]. Moreover, due to the excellent oxygen buffering property of ceria, they present also a high interest for heterogeneous catalysis. The most important catalytic reactions using ceria-based nanomaterials are reduction of NO [6,7], CO oxidation [8], and Water Gas Shift [9] reactions. 
In many cases, the redox properties and chemical activity of pure ceria can be enhanced by introducing different types of metals (e.g., $\mathrm{Zr}, \mathrm{Ca}, \mathrm{Cu}, \mathrm{Tb}, \mathrm{Mn}$, etc.) into the oxide [10-12]. At a structural level, a dopant or second metal can introduce stress into the lattice of an oxide host, inducing the formation of defects with a high chemical activity. On the other hand, the lattice of the oxide host can impose non-typical coordination modes on the dopant element with a subsequent perturbation in the dopant chemical properties. Finally, metal-metal or metal-oxygen-metal interactions in mixed-metal oxides can lead to electronic properties not seen in single-metal oxides [13]. Also, according to the dopant nature a different effect on the formation of oxygen vacancies in ceria occurs which may lead to tunable performance of the final mixed oxide.

With the challenge of replacing the expensive and scarcely available noble metal catalysts, scientists have been encouraged to use transition metal oxide nanoparticles. Recently, it has been shown that $\mathrm{CeO}_{2}-\mathrm{CuO}$ mixed oxide nanomaterials were promising nanocatalysts for the preferential oxidation of $\mathrm{CO}$ [14]. Copper oxide nanomaterials are applied in various areas: gas sensors [15], biosensors [16], batteries [17], high temperature superconductors [18], solar energy conversion [19], field emission emitters [20], and catalysis [21]. It has been reported that the efficiency of $\mathrm{CeO}_{2}-\mathrm{CuO}$ nanocatalysts could be related to synergetic interactions between $\mathrm{CeO}_{2}$ and $\mathrm{CuO}$ promoting special redox properties at their interface [22]. However, it is worth noting that the redox properties of the obtained mixed oxides depend on the preparation methods promoting different catalytic performance due to the various states of dispersion of copper [23].

$\mathrm{CeO}_{2}-\mathrm{CuO}$ nanoparticles have been prepared by several methods. For example, the material synthesized by the hydrothermal method presented a high performance for selective oxidation of $\mathrm{CO}$ in excess $\mathrm{H}_{2}$ [24]. In addition, Szabova et al. reported another method that consists of the deposition of metallic $\mathrm{Cu}$ onto a previously prepared $\mathrm{CeO}_{2}$ surface in 12 consecutive steps [25]. Gurbani et al. reviewed other methods to prepare $\mathrm{Cu}-\mathrm{Ce}$ mixed oxides, such as co-precipitation, sol-gel, and urea-nitrate combustion [26]. The main disadvantages of the cited methods are the requirements of high temperature (min. $80^{\circ} \mathrm{C}$ ) for several hours, involving high energy input and/or sophisticated techniques or equipment. In order to overcome this environmental impact, a new promising method for the synthesis of metal and metal oxide nanoparticles was recently developed, based on the use of oil-in-water $(\mathrm{O} / \mathrm{W})$ microemulsions as confined reaction media [27]. In addition to the advantages of the traditional water-in-oil (W/O) microemulsion method [28-30], namely, a high control of particle size, a high purity, and good chemical homogeneity under mild conditions, the $\mathrm{O} / \mathrm{W}$ microemulsion method has the advantage of requiring lower organic solvent concentrations, as the predominant component is aqueous [27,31]. The $\mathrm{O} / \mathrm{W}$ microemulsion reaction method, firstly reported by our research group in 2009 [27] for the preparation of metal and metal oxide nanoparticles, consists of the use of organometallic precursors, dissolved within nanometer scale oil droplets (stabilized by surfactant), and dispersed in a continuous aqueous phase. The thermodynamic stability of microemulsions maintains the oil phase (carrying the metal precursors) and the aqueous phase (containing the precipitating agent) intimately mixed leading to an increased oil-water interface. The confined media at the nanometer level created by the microemulsion environment may lead to an increased synergy between oxides at their interface which may result in better properties and improved performance.

The present work reports on the synthesis of mixed $\mathrm{Cu} / \mathrm{Ce}$ oxide nanoparticles using the mild oil-in-water microemulsion reaction method. Characteristics of the as-obtained and calcined nanomaterials were compared as a function of $\mathrm{Cu} / \mathrm{Ce}$ molar ratio in order to determine the maximum $\mathrm{Cu}$ content that could be incorporated into the $\mathrm{CeO}_{2}$ crystal lattice with a good $\mathrm{Cu}$ dispersion, which is a relevant characteristic in catalytic applications. Magnetic, optical ( $E_{\mathrm{g}}$ as a function of $\mathrm{Cu}$ content), and photocatalytic properties are presented. 


\section{Results}

\subsection{Microemulsion Formulation and Synthesis of $\mathrm{Cu} / \mathrm{Ce}$ Nanoparticles}

Phase behavior of the Water/Synperonic ${ }^{\circledR}$ 91/5/Isooctane system was investigated in order to define the compositions and temperatures at which microemulsions were formed, as detected by their transparency, low viscosity and optical isotropy (lack of birefringence) and high water content. The results obtained together with previous studies [27,31,32], allowed the selection of a specific composition with a water/surfactant/oil (W/S/O) weight ratio of 64.5/21.5/14 forming $\mathrm{O} / \mathrm{W}$ microemulsions near room temperature. Copper (II) and cerium (III) 2-ethylhexanoate precursors were dissolved in isooctane forming the oil phase. Thus, the strategy was to vary the ratio of $\mathrm{Cu}$ (II) and Ce (III) 2-ethylhexanoate precursors dissolved in the oil phase, in order to have $\mathrm{Cu} / \mathrm{Ce}$ molar ratios from 0/100 to 50/50. Then, the interval of temperature at which microemulsions with precursors were formed was investigated. The obtained $\mathrm{O} / \mathrm{W}$ microemulsions were transparent and fluid, with bluish-green color due to the presence of copper precursor at various concentrations. Incorporation of the metal precursors promoted a shift in the temperature range at which $\mathrm{O} / \mathrm{W}$ microemulsions were formed. The microemulsion without precursor was formed at a temperature range of $24-26^{\circ} \mathrm{C}$; whereas, when precursors where incorporated into the oil phase, the temperature needed for microemulsion formation was higher. Furthermore, as the content of copper precursor was increased, a higher temperature was needed for the formation of $\mathrm{O} / \mathrm{W}$ microemulsions (Table 1).

Table 1. Temperature range of microemulsion formation and temperature used for reactions, as a function of $\mathrm{Cu} / \mathrm{Ce}$ molar ratio. The surfactant/oil (S/O) weight ratio was kept constant at 25/75 and the oil phase concentration was $14 \mathrm{wt} \%$ (solution of isooctane and metal precursor)-ME: Microemulsion.

\begin{tabular}{ccc}
\hline Molar Ratio Cu/Ce & ME Temperature Range $\left({ }^{\circ} \mathbf{C}\right)$ & Reaction Temperature $\left({ }^{\circ} \mathbf{C}\right)$ \\
\hline $0 / 0$ & $24-26$ & - \\
$0 / 100$ & $26-28$ & 27 \\
$5 / 95$ & $26-29$ & 27.5 \\
$10 / 90$ & $26-29$ & 27.5 \\
$20 / 80$ & $27-29$ & 28 \\
$30 / 70$ & $28-30$ & 29 \\
$35 / 65$ & $28-30$ & 29 \\
$40 / 60$ & $29-31$ & 30 \\
$50 / 50$ & $29-31$ & 30 \\
\hline
\end{tabular}

In order to form the $\mathrm{Cu} / \mathrm{Ce}$ mixed oxide nanoparticles, $\mathrm{NaOH}(2.5 \mathrm{M})$ was added, leading to the precipitation of $\mathrm{Cu} / \mathrm{Ce}$ mixed oxide nanoparticles.

\subsection{Characterization of $\mathrm{Cu} / \mathrm{Ce}$ Oxide $\mathrm{NPS}$}

\subsubsection{High Resolution Transmission Electron Microscopy (HRTEM)}

Assessment of crystallinity and particle size was carried out by HRTEM (JEOL-2200FS, Tokyo, Japan). Figure 1 shows high resolution TEM images of non-calcined (as prepared) mixed oxide nanoparticles with different $\mathrm{Cu} / \mathrm{Ce}$ molar ratio (from 0/100 to 30/70). In all cases, the particles formed agglomerates of different sizes. These agglomerates are comprised of many nanoparticles with a diameter in the order of 2-3 nm. This homogeneous morphology and size was observed in samples containing $\mathrm{Cu} / \mathrm{Ce}$ molar ratio from 0/100 to 30/70, as observed in Figure 1a-e, which are representative images of these samples. Crystalline features can be observed in these samples, indicating that the agglomerates were made up of small nanocrystals, and the size of the nanocrystals as well as the agglomeration decreased as the $\mathrm{Cu}$ content was increased (this can be seen in Figure 1 as well as in Figure S1, which shows a general low magnification view of all samples). Analysis of the Fast Fourier Transform (FFT) images of several crystals for samples with $\mathrm{Cu} / \mathrm{Ce}$ molar ratio up to 
$20 / 80$, indicated the presence of the $\{111\}$ plane of cubic $\mathrm{CeO}_{2}$ (d-spacing of $0.3125 \mathrm{~nm}$, ICDD PDF No. 98-001-1731; examples of analyzed crystals of all samples are shown in Supplementary Materials, insets to Figure S1 and in more detail Figure S2). For these samples, only small crystals corresponding to the $\mathrm{CeO}_{2}$ cubic fluorite phase were identified. For the sample with $\mathrm{Cu} / \mathrm{Ce}$ molar ratio 30/70, the crystalline features were more disordered.
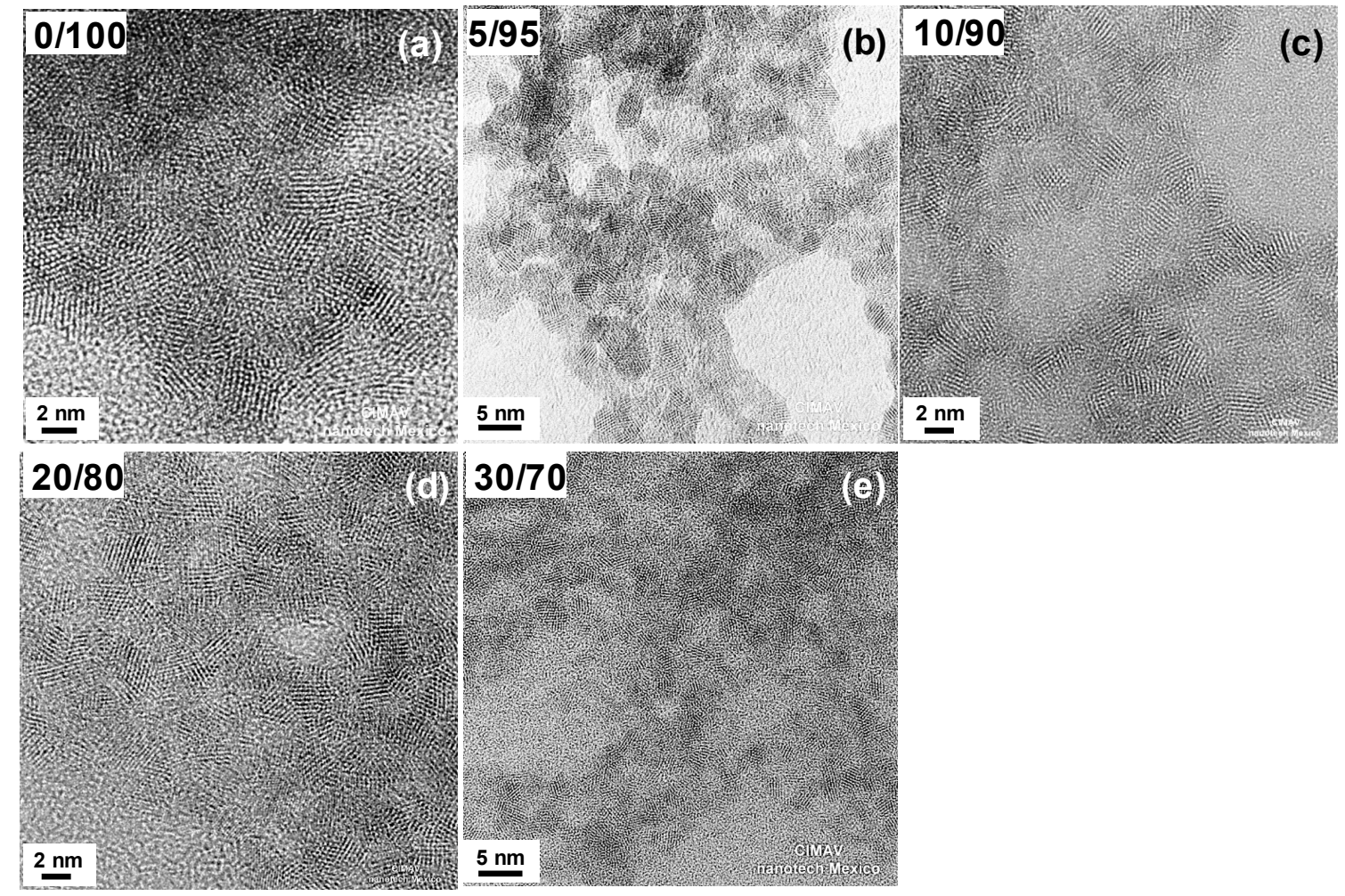

Figure 1. TEM micrographs of the synthesized nanomaterials (as obtained): (a) $\mathrm{CeO}_{2}$; (b) $\mathrm{Cu}_{0.05} \mathrm{Ce}_{0.95} \mathrm{O}_{2-\delta} ;$ (c) $\mathrm{Cu}_{0.10} \mathrm{Ce}_{0.90} \mathrm{O}_{2-\delta} ;$ (d) $\mathrm{Cu}_{0.20} \mathrm{Ce}_{0.80} \mathrm{O}_{2-\delta} ;(\mathbf{e}) \mathrm{Cu}_{0.30} \mathrm{Ce}_{0.70} \mathrm{O}_{2-\delta}$.

Figure 2a-i shows TEM micrographs for samples with $\mathrm{Cu} / \mathrm{Ce}$ molar ratio 35/65, 40/60 and 50/50. For these samples, two morphologies were identified. At Cu/Ce molar ratio 35/65, a minor population of thin nanotapes of $\sim 10-20 \mathrm{~nm}$ width in coexistence with the small nanoparticles was also found (Figure $2 \mathrm{a}-\mathrm{c}$ ). For samples with $\mathrm{Cu} / \mathrm{Ce}$ molar ratio 40/60 and 50/50, the nanotapes were more abundant with a greater tendency to self-assemble (Figure $2 \mathrm{~d}-\mathrm{i}$ ). These observations indicate that above $\mathrm{Cu} / \mathrm{Ce}$ molar ratio 30/70, $\mathrm{Cu}$ atoms are no longer incorporated into the $\mathrm{CeO}_{2}$ matrix (or its concentration is too high to remain well-dispersed), promoting their growth into thin $\mathrm{CuO}$ nanotapes.

As the $\mathrm{Cu} / \mathrm{Ce}$ molar ratio was increased above 30/70, the size of the nanocrystalline domains decreased for the small nanoparticles morphology (Figure $2 b, e, h$ ). In fact, for the samples with $\mathrm{Cu} / \mathrm{Ce}$ molar ratio 40/60 and 50/50, the crystalline features of the mixed oxide nanoparticles were scarce, thus this component of the material was practically amorphous, as shown in Figure 2e,h. On the other hand, Figure 2c,f,i show representative high-resolution images of the thin nanotapes. FFT analysis of the nanotape in Figure 2c indicates the presence of planes $\{111\},\{-112\},\{020\},\{022\},\{220\},\{311\}$ and $\{-131\}$ of monoclinic $\mathrm{CuO}$ (corresponding to d-spacings of $0.232 \mathrm{~nm}, 0.196 \mathrm{~nm}, 0.171 \mathrm{~nm}, 0.142 \mathrm{~nm}$, $0.138 \mathrm{~nm}, 0.130 \mathrm{~nm}$ and $0.109 \mathrm{~nm}$, respectively; ICDD PDF No. 98-000-6038). Similar results were obtained with the FFT analysis of the nanotapes in Figure 2f,i. It was observed that the continuity of the crystalline planes of the monoclinic $\mathrm{CuO}$ nanotapes has a long range. The dimensions of these particles was about 10-20 $\mathrm{nm}$ in width and several hundred nanometers in length. Similar results were obtained for nanotapes of the samples with $\mathrm{Cu} / \mathrm{Ce}$ molar ratio 35/65 and 50/50. Thus, at $\mathrm{Cu} / \mathrm{Ce}$ 
molar ratio $\geqslant 35 / 65$ crystalline, monoclinic $\mathrm{CuO}$ nanotapes were formed under mild conditions, in addition to the mixed $\mathrm{Cu} / \mathrm{Ce}$ oxide small nanoparticles.

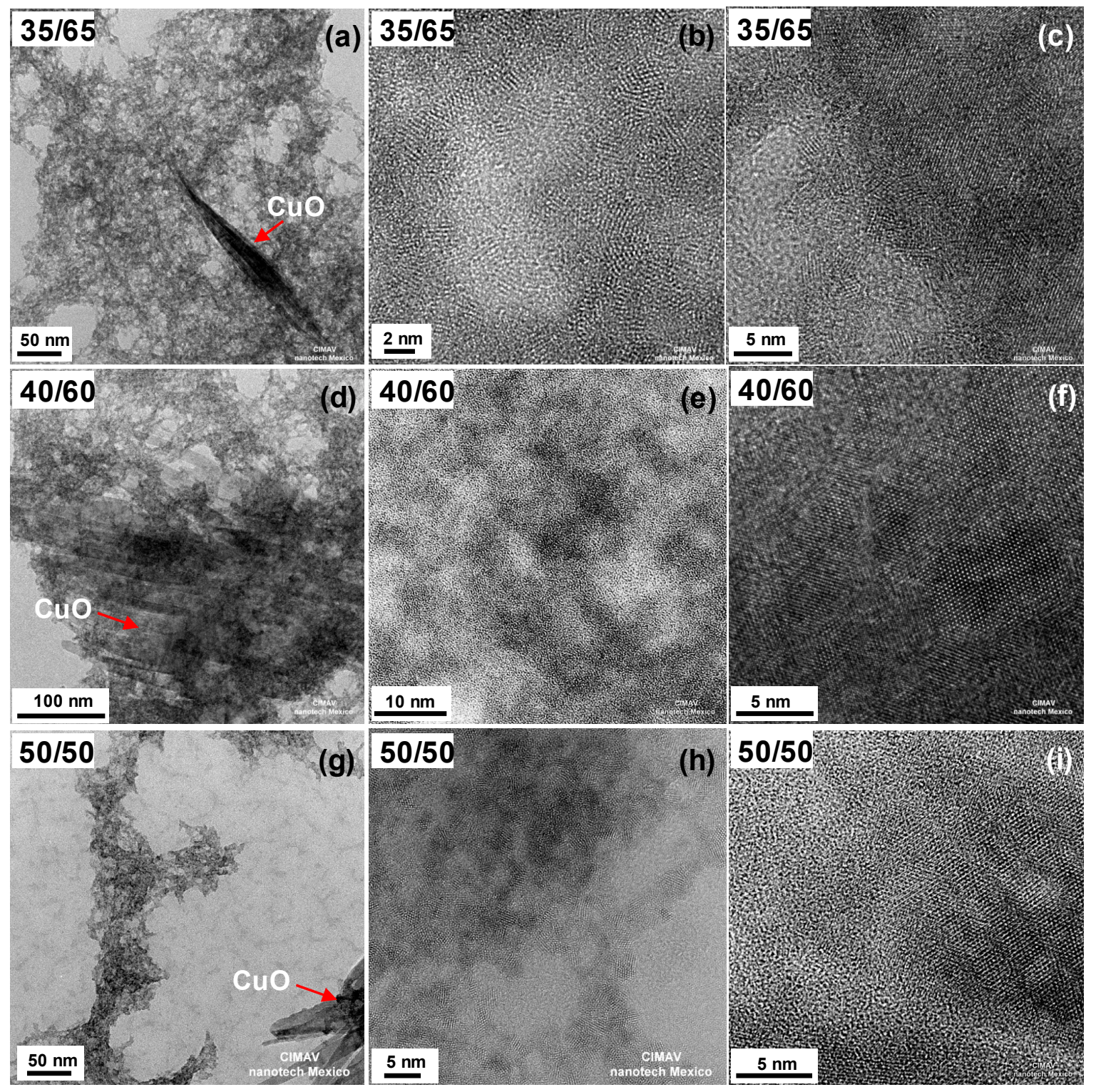

Figure 2. TEM micrographs of the synthesized nanomaterials (as obtained): $\mathrm{Cu}_{0.35} \mathrm{Ce}_{0.65} \mathrm{O}_{2-\delta}$ (a) NPs and nanotape morphology; (b) NPs morphology and (c) nanotape morphology; $\mathrm{Cu}_{0.40} \mathrm{Ce}_{0.60} \mathrm{O}_{2-\delta}$ (d) NPs and nanotape morphology; (e) NPs morphology and (f) nanotape morphology; $\mathrm{Cu}_{0.50} \mathrm{Ce}_{0.50} \mathrm{O}_{2-\delta}$ (g) NPs and nanotape morphology; (h) NPs morphology and (i) nanotape morphology. Red arrows indicate $\mathrm{CuO}$ nanotapes (or nanotapes assemblies).

Evolution of the phases was confirmed by acquiring selected area electron diffraction patterns (SAED). Examples of diffraction patterns of samples synthesized with $\mathrm{Cu} / \mathrm{Ce}$ molar ratio 5/95 and 40/60 are shown in Figure 3a-c. The pattern in Figure 3a show the faint rings characteristic of polycrystalline materials for the sample with $\mathrm{Cu} / \mathrm{Ce}$ molar ratio 5/95; similar results were obtained up to $\mathrm{Cu} / \mathrm{Ce}$ molar ratio 30/70, although as the $\mathrm{Cu} / \mathrm{Ce}$ molar ratio was increased, the rings became less defined, in agreement with the observations from HRTEM images. These rings were indexed by comparing with the corresponding powder diffraction file (PDF) from the International Centre for Diffraction Data (ICDD): face centered cubic Cerium Oxide ( $\mathrm{CeO}_{2}$ ICDD PDF No. 98-001-1731). For 
the sample with $\mathrm{Cu} / \mathrm{Ce}$ molar ratio 40/60, no defined rings were observed in the material with small nanoparticle morphology, as shown in Figure 3b, confirming the amorphous nature of these particles; similar SAED patterns were obtained for the nanoparticle morphology of samples with $\mathrm{Cu} / \mathrm{Ce}$ molar ratios 35/65 and 50/50. In contrast, the diffraction spots shown in Figure 3c correspond to a nanotape crystal of the sample with $\mathrm{Cu} / \mathrm{Ce}$ molar ratio 40/60, which were indexed as the diffraction planes $\{111\},\{110\},\{200\},\{020\},\{-311\},\{022\},\{113\},\{400\},\{-131\}$, and $\{220\}$ corresponding to the monoclinic $\mathrm{CuO}$ phase (ICDD PDF No. 98-000-6038). Similar results were obtained for the nanotape morphology of samples with $\mathrm{Cu} / \mathrm{Ce}$ molar ratio $35 / 65$ and 50/50.
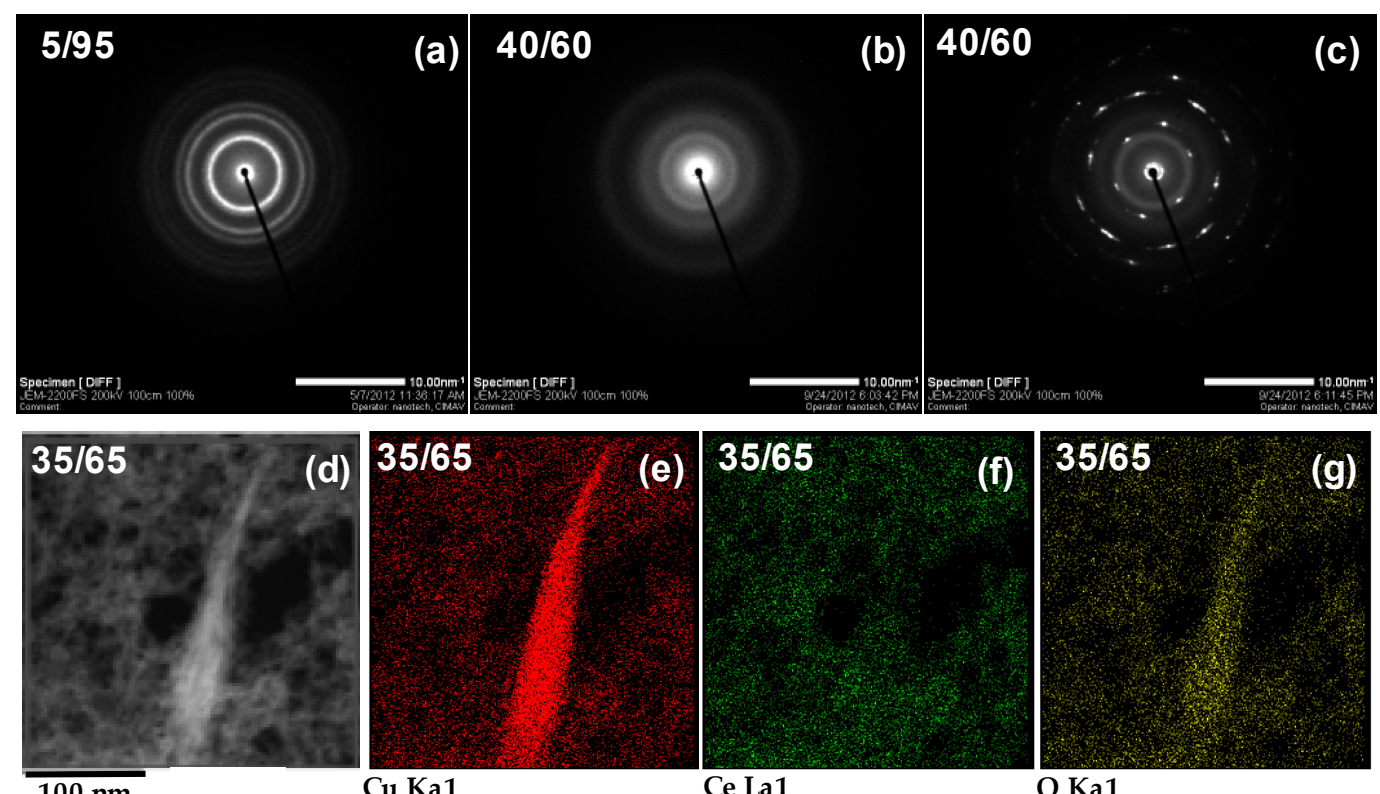

Figure 3. Electron diffraction patterns of the selected samples (as obtained): (a) $\mathrm{Cu}_{0.05} \mathrm{Ce}_{0.95} \mathrm{O}_{2-\delta}$; (b) $\mathrm{Cu}_{0.40} \mathrm{Ce}_{0.60} \mathrm{O}_{2-\delta}$ (corresponding to nanoparticle morphology); (c) $\mathrm{Cu}_{0.50} \mathrm{Ce}_{0.50} \mathrm{O}_{2-\delta}$ (corresponding to nanotape morphology); EDX elemental mapping for the $\mathrm{Cu}_{0.35} \mathrm{Ce}_{0.65} \mathrm{O}_{2-\delta}$ sample (as obtained):

(d) bright field image; (e) Cu mapping; (f) Ce mapping; (g) O mapping.

In order to analyze the chemical element distribution and clearly relate it with the different morphologies and phases found by HRTEM analysis for certain samples, Energy Dispersive X-ray Spectroscopy (EDX) elemental mapping of the sample containing $\mathrm{Cu} / \mathrm{Ce}$ molar ratio 35/65 was carried out and the results are displayed in Figure $3 \mathrm{~d}-\mathrm{g}$. This sample was deposited onto an Au TEM grid in order to avoid contribution from the conventional $\mathrm{Cu}$ grid. The elements detected were $\mathrm{Cu}, \mathrm{Ce}$, and $\mathrm{O}$. A $\mathrm{Cu}$ signal was detected in both the nanoparticles and the nanotapes. A cerium signal was observed in the nanoparticles, whilst an oxygen signal was found homogeneously distributed in the entire sample. This information corroborates the aforementioned assignment of phases: in the small nanoparticles with cubic $\mathrm{CeO}_{2}$ structure, $\mathrm{Cu}$ and $\mathrm{Ce}$ are homogeneously distributed suggesting the formation of a mixed $\mathrm{Cu}$-Ce oxide or an excellent dispersion of $\mathrm{Cu}$ onto $\mathrm{CeO}_{2}$, whilst the thin nanotapes are composed only by $\mathrm{CuO}$.

\subsubsection{X-ray Diffraction}

The overall crystallinity of the non-calcined (as obtained) samples was further studied by XRD and results are presented in Figure 4. Below $\mathrm{Cu} / \mathrm{Ce}$ molar ratio 35/65, the crystal structure of mixed $\mathrm{Cu} / \mathrm{Ce}$ oxide nanoparticles $\left(\mathrm{Cu}_{x} \mathrm{Ce}_{1-x} \mathrm{O}_{2-\delta}\right)$ was identified with the characteristic reflections of the fluorite-type face-centered cubic ceria $\left(\mathrm{CeO}_{2}\right)$ phase (ICDD PDF No. 98-001-1731). As the content of $\mathrm{Cu}$ increased, the characteristic reflections became wider, indicating lower crystallinity, in agreement 
with the results from HRTEM, which showed smaller and less defined crystalline domains. As shown in Table 2, the position of the main reflection was shifted from $28.71^{\circ}\left(\mathrm{CeO}_{2}\right)$ to $29.35^{\circ}(\mathrm{Cu} / \mathrm{Ce}$ molar ratio 35/65), which may suggest the incorporation of $\mathrm{Cu}$ into the $\mathrm{CeO}_{2} \mathrm{FCC}$ lattice, since a shift of $2 \theta$ to larger values is an indication of smaller characteristic lattice dimensions, which is in agreement with the smaller size of $\mathrm{Cu}^{2+}$ as compared to $\mathrm{Ce}^{3+}$ or $\mathrm{Ce}^{4+}$ ions. However, due to the large broadening of the reflections of the as-obtained samples, this shift may be overestimated. On the other hand, for the sample with $\mathrm{Cu} / \mathrm{Ce}$ molar ratio 35/65, additional reflections were detected and confirmed the presence of $\mathrm{CuO}$ monoclinic phase (ICDD PDF No. 98-000-6038). Thus, at Cu/Ce molar ratios 35/65, $40 / 60$, and 50/50, samples were composed of a mixture of oxides with a main phase of $\mathrm{Cu} / \mathrm{Ce}$ mixed oxide and an excess of monoclinic $\mathrm{CuO}$ phase. In addition, in agreement with HRTEM results at the compositions with $\mathrm{Cu} \geqslant 35 \%$, although the characteristic reflections for cubic ceria were observed, these reflections were very wide, indicating that crystallinity was rather poor. The crystallite size $\left(d_{\mathrm{XRD}}\right)$ of the $\mathrm{Cu} / \mathrm{Ce}$ mixed oxide nanoparticles was estimated using the Scherrer equation as a function of $\mathrm{Cu} / \mathrm{Ce}$ molar ratio. The $d_{\mathrm{XRD}}$ and the corresponding $2 \theta$ for all samples are collected in Table 2.

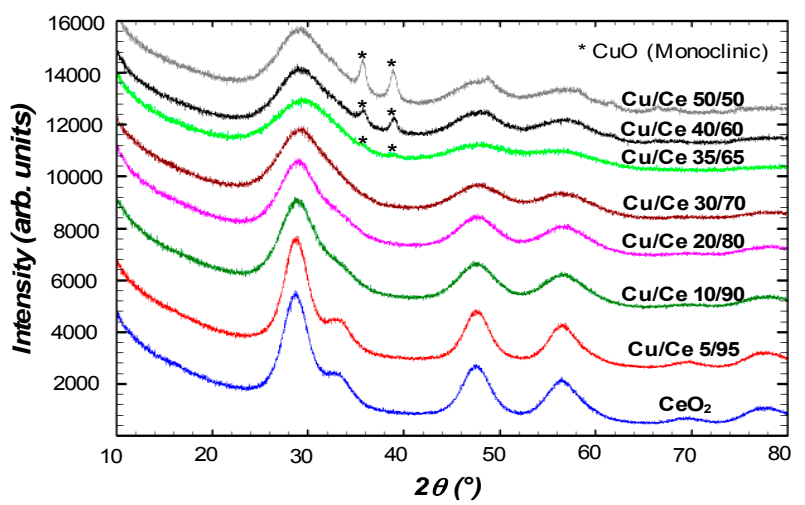

Figure 4. X-ray diffraction (XRD) patterns of samples (non-calcined) as a function of $\mathrm{Cu} / \mathrm{Ce}$ molar ratio. The reflections marked as $\left(^{*}\right)$ are consistent with monoclinic $\mathrm{CuO}$; the rest of the reflections are consistent with cubic fluorite-type ceria.

Table 2. Crystallite size of $\mathrm{Cu} / \mathrm{Ce}$ mixed oxide nanoparticles estimated using the Scherrer equation as a function of $\mathrm{Cu} / \mathrm{Ce}$ molar ratio (as obtained samples).

\begin{tabular}{ccc}
\hline Sample $\mathbf{C u} / \mathrm{Ce}$ Molar Ratio & Crystallite Size $\left(\boldsymbol{d}_{\mathbf{X R D}}\right.$ in $\left.\mathbf{n m}\right)$ & $\left.\mathbf{2 \theta} \boldsymbol{(}^{\circ}\right)$ \\
\hline $\mathrm{CeO}_{2}$ & 3.1 & 28.71 \\
$\mathrm{Cu} / \mathrm{Ce} 5 / 95$ & 2.9 & 28.73 \\
$\mathrm{Cu} / \mathrm{Ce} 10 / 90$ & 2.5 & 28.88 \\
$\mathrm{Cu} / \mathrm{Ce} 20 / 80$ & 2.4 & 28.93 \\
$\mathrm{Cu} / \mathrm{Ce} \mathrm{30/70}$ & 2.1 & 29.12 \\
$\mathrm{Cu} / \mathrm{Ce} \mathrm{35/65}$ & 1.8 & 29.35 \\
$\mathrm{Cu} / \mathrm{Ce} 40 / 60$ & 2.1 & 29.30 \\
$\mathrm{Cu} / \mathrm{Ce} \mathrm{50/50}$ & 2.1 & 29.30 \\
\hline
\end{tabular}

Samples containing $\mathrm{Cu} / \mathrm{Ce}$ molar ratios $20 / 80$ and $30 / 70$ were calcined at $400{ }^{\circ} \mathrm{C}$ and $500{ }^{\circ} \mathrm{C}$ so that the incorporation of $\mathrm{Cu}$ into the $\mathrm{CeO}_{2}$ crystal lattice could be investigated with consistence. The characteristic reflections of the fluorite-type cubic crystal structure were still observed for both calcined materials except that their reflections were much more defined than before calcination (Figure 5a). This observation can be explained by the increase of crystallite size as approximated by the Scherrer equation and values are presented in Table 3. The main reflection presented a much lower shift in the calcined samples, remaining close to $28.7^{\circ}\left(28.74^{\circ}-28.77^{\circ}\right)$, in contrast to the corresponding non-calcined samples $\left(28.93^{\circ}-29.12^{\circ}\right)$. The nanomaterial containing $\mathrm{Cu} / \mathrm{Ce}$ molar ratio $20 / 80$ presented 
no additional reflections after calcination. However, the sample with $\mathrm{Cu} / \mathrm{Ce}$ molar ratio 30/70 presented additional reflections, characteristic of monoclinic CuO. HRTEM images in Figure 5b,c confirmed the formation of the $\mathrm{CuO}$ phase in the form of elongated structures upon calcination as well as the increased crystallinity of the $\mathrm{Cu} / \mathrm{Ce}$ mixed oxide nanoparticles.
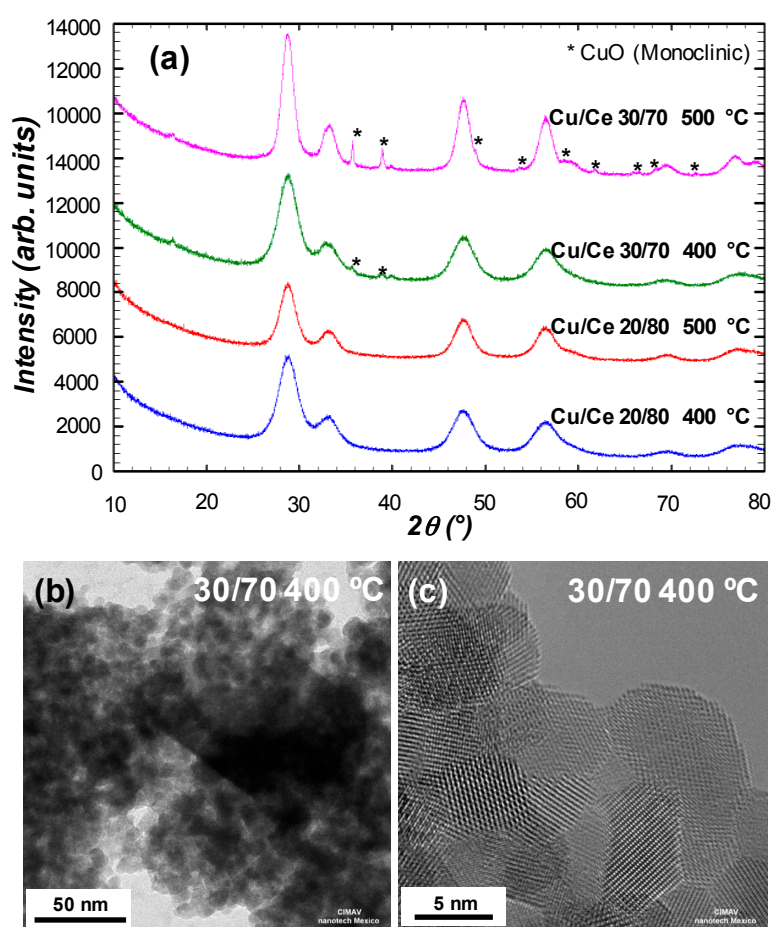

Figure 5. (a) XRD patterns of samples with $\mathrm{Cu} / \mathrm{Ce}$ molar ratio $20 / 80$ and $30 / 70$, calcined at $400{ }^{\circ} \mathrm{C}$ and $500{ }^{\circ} \mathrm{C}$. High-resolution transmission electron microscope (HRTEM) images of $\mathrm{Cu} / \mathrm{Ce} 30 / 70$ calcined at $500{ }^{\circ} \mathrm{C}$; (b) showing a mixture of $\mathrm{Cu} / \mathrm{Ce}$ mixed oxide nanoparticles and elongated $\mathrm{CuO}$; and (c) atomic resolution of $\mathrm{Cu} / \mathrm{Ce}$ mixed oxide nanoparticles.

Table 3. Crystallite size of the calcined nanomaterials calculated by Scherrer equation as a function of $\mathrm{Cu} / \mathrm{Ce}$ molar ratio.

\begin{tabular}{ccc}
\hline $\mathbf{C u} / \mathrm{Ce}$ Molar Ratio Calcination Temperature & Crystallite Size $\left(\boldsymbol{d}_{\mathbf{X R D}}\right.$ in $\left.\mathbf{n m}\right)$ & $\mathbf{2 \theta}\left(\mathbf{(}^{\circ}\right)$ \\
\hline $\mathrm{Cu} / \mathrm{Ce} 20 / 80500^{\circ} \mathrm{C}$ & 5.2 & 28.76 \\
$\mathrm{Cu} / \mathrm{Ce} 30 / 70500^{\circ} \mathrm{C}$ & 6.9 & 28.74 \\
$\mathrm{Cu} / \mathrm{Ce} 20 / 80400^{\circ} \mathrm{C}$ & 4.4 & 28.77 \\
$\mathrm{Cu} / \mathrm{Ce} 30 / 70400^{\circ} \mathrm{C}$ & 4.3 & 28.75 \\
\hline
\end{tabular}

\subsubsection{Raman Spectroscopy}

Raman Spectroscopy was used for further investigation of the structure of selected non-calcined (as prepared) and calcined samples. The main feature of such $\mathrm{CeO}_{2}$ based materials is the $\mathrm{F}_{2 \mathrm{~g}}$ Raman active mode of the $\mathrm{CeO}_{2}$ fluorite phase, which for bulk $\mathrm{CeO}_{2}$ it is located at $465 \mathrm{~cm}^{-1}$ [33], whereas for nanosized $\mathrm{CeO}_{2}$ materials it has been reported in the range of $460-466 \mathrm{~cm}^{-1}$ [34]. The Raman spectra for these fluorite-type oxide structures are dominated by oxygen lattice vibrations and are sensitive to crystalline symmetry [35]. Figure 6a,b shows the Raman spectra; for comparison purposes, the intensities have been normalized. The samples display the characteristic and relatively intense $\mathrm{F}_{2 \mathrm{~g}}$ band, centered at 452 and $455 \mathrm{~cm}^{-1}$ for $\mathrm{CeO}_{2}$ as-obtained and calcined at $500{ }^{\circ} \mathrm{C}\left(\mathrm{CeO}_{2}\right.$ and $\mathrm{CeO}_{2}$ $500{ }^{\circ} \mathrm{C}$ ); 447 and $451 \mathrm{~cm}^{-1}$ for $\mathrm{Cu} / \mathrm{Ce} 5 / 95$ and $\mathrm{Cu} / \mathrm{Ce} 5 / 95500{ }^{\circ} \mathrm{C} ; 443 \mathrm{~cm}^{-1}$ for Cu/Ce 10/90; 446 and $447 \mathrm{~cm}^{-1}$ for $\mathrm{Cu} / \mathrm{Ce} 20 / 80$ and $\mathrm{Cu} / \mathrm{Ce} 20 / 80500^{\circ} \mathrm{C}$; and 447 and $449 \mathrm{~cm}^{-1}$ for Cu/Ce 30/70 and 
$\mathrm{Cu} / \mathrm{Ce} 30 / 70500{ }^{\circ} \mathrm{C}$ (see shift in the inset of Figure 6b). The other important feature of the Raman spectra is the band extending from 500 to $650 \mathrm{~cm}^{-1}$ (Figure 6c); this band has been assigned to oxygen vacancies [36]. Other bands were observed between 100 and $300 \mathrm{~cm}^{-1}$.
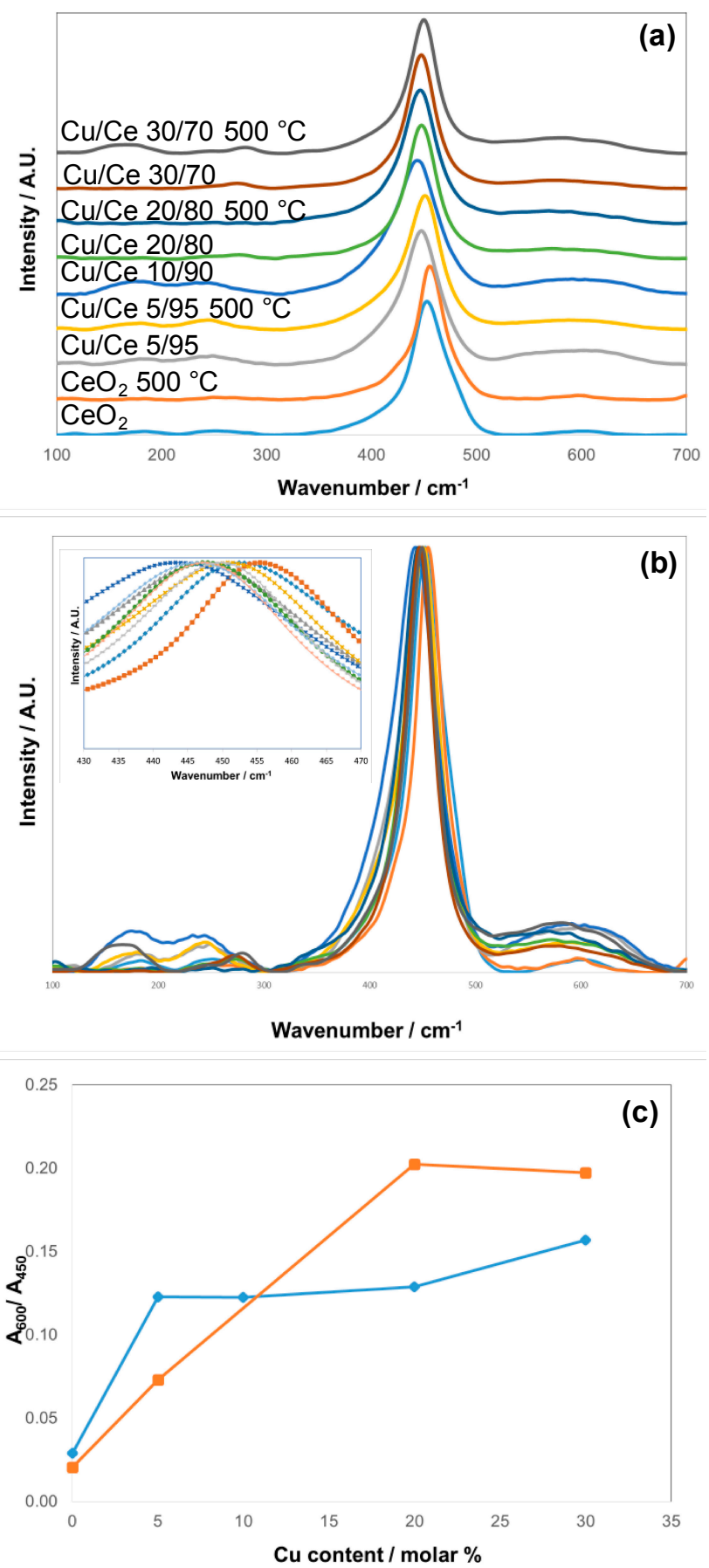

Figure 6. (a) Raman spectra of $\mathrm{CeO}_{2}$ and $\mathrm{Cu} / \mathrm{Ce}$ mixed oxides (as-obtained and calcined at $500{ }^{\circ} \mathrm{C}$ ); (b) Same data without offset for comparison of relative intensity of the different bands; inset: zoom into the $\mathrm{F}_{2 \mathrm{~g}}$ Raman active mode; (c) $\mathrm{A}_{600} / \mathrm{A}_{450}$ for assessment of relative oxygen vacancies as a function of

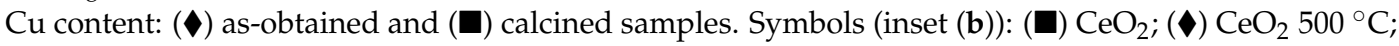

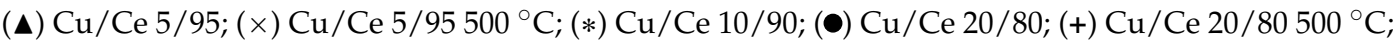
(-) Cu/Ce 30/70; (一) Cu/Ce 30/70 $500{ }^{\circ} \mathrm{C}$. 


\subsection{Magnetic Properties}

Assessment of the magnetic properties of selected samples was carried out at $5 \mathrm{~K}\left(-268.15^{\circ} \mathrm{C}\right)$ in order to find out the influence of incorporating $\mathrm{Cu}$ into $\mathrm{CeO}_{2}$ (Figure 7). At $300 \mathrm{~K}$ the magnetic response of $\mathrm{CeO}_{2}$ nanoparticles was very small upon applying a magnetic field up to $50 \mathrm{kG}$ whereas at $5 \mathrm{~K}$, a certain magnetic response was noticed. This magnetic behavior may be explained by the surface defects of $\mathrm{CeO}_{2}$ nanoparticles. A comparison of the magnetic properties of two $\mathrm{Cu} / \mathrm{Ce}$ mixed oxides was also carried out (Figure 7). At a higher amount of $\mathrm{Cu}$ in the $\mathrm{CeO}_{2}$ lattice, a higher magnetization response is achieved. Indeed, for pure $\mathrm{CeO}_{2}$ the maximum magnetization response at $\mathrm{H}=5 \mathrm{kG}$ is $\sim 0.25 \mathrm{emu} / \mathrm{g}$ whereas for $\mathrm{Cu} / \mathrm{Ce} 20 / 80$, the maximum magnetization response is $\sim 2.1 \mathrm{emu} / \mathrm{g}$. It should be noted that by applying a magnetic field up to $50 \mathrm{kG}$ the magnetization saturation was not achieved which means that all the spins were not yet aligned at lower magnetic fields. Therefore, by doping $\mathrm{CeO}_{2}$ lattice with $\mathrm{Cu}$, the magnetic properties could be tuned from diamagnetic to paramagnetic behavior since no hysteresis could be detected.

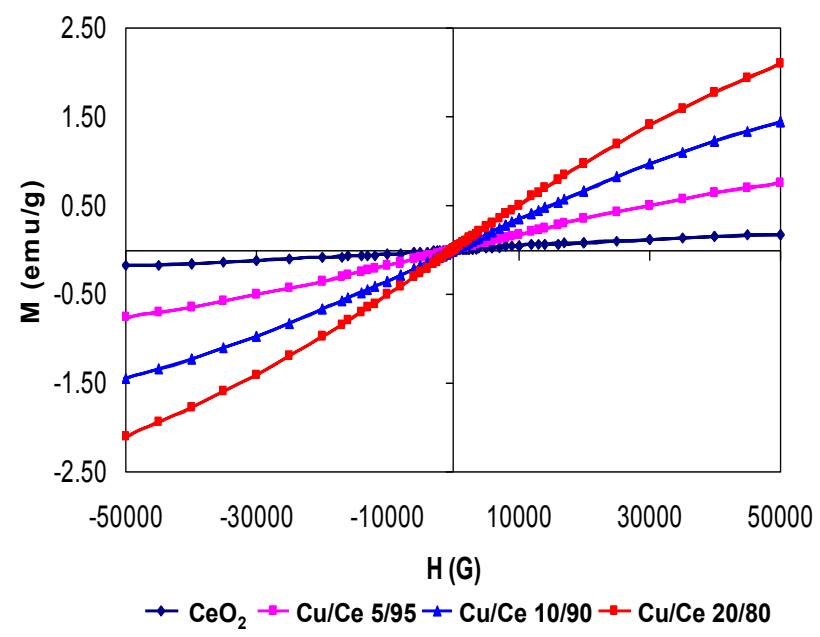

Figure 7. Magnetization as a function of the magnetic field at $5 \mathrm{~K}$ of nanoparticles $\left(\mathrm{CeO}_{2}\right.$, $\mathrm{Cu}_{0.05} \mathrm{Ce}_{0.95} \mathrm{O}_{2-\delta}(\mathrm{Cu} / \mathrm{Ce} 5 / 95), \mathrm{Cu}_{0.10} \mathrm{Ce}_{0.90} \mathrm{O}_{2-\delta}\left(\mathrm{Cu} / \mathrm{Ce} \mathrm{10/90)}, \mathrm{Cu}_{0.20} \mathrm{Ce}_{0.80} \mathrm{O}_{2-\delta}(\mathrm{Cu} / \mathrm{Ce} 20 / 80)\right.$.

\subsection{Optical Properties and Photocatalytic Degradation of Indigo Carmine}

The bandgap energy $\left(E_{g}\right)$ of $\mathrm{Cu} / \mathrm{Ce}$ samples was calculated by Kubelka-Munk function [37] as shown in Figure 8. It is clearly observed that all samples exhibited absorption in the visible light interval, and the $E_{\mathrm{g}}$ values are lower than $3.0 \mathrm{eV}$, calculated $E_{\mathrm{g}}$ are shown in Table 4 . The $E_{g}$ value of $\mathrm{CeO}_{2}$ nanoparticles was $2.91 \mathrm{eV}$, whereas samples containing different $\mathrm{Cu} / \mathrm{Ce}$ molar ratio resulted in $E_{g}$ values in the order of $2.85-2.27 \mathrm{eV}$.

The photodegradation of Indigo Carmine using $\mathrm{Cu} / \mathrm{Ce}(30 / 70$ and 35/65) oxides as photocatalyst was explored under visible light. Figure 9 shows the evolution of $\mathrm{C} / \mathrm{C}_{0}$ including the curve obtained from the photolysis and the use of the $\mathrm{CeO}_{2}$ sample as photocatalyst for comparison purposes. Accordingly, it is observed that $\mathrm{CeO}_{2}$ immediately adsorbs the dye completely, whereas samples containing copper show less dye adsorption, increasing the photodegradation of the dye. In this case, the use of $\mathrm{Cu} / \mathrm{Ce}$ samples as photocatalyst allow the photodegradation of about $60 \%$ of the initial dye concentration after $3 \mathrm{~h}$ for sample $\mathrm{Cu} / \mathrm{Ce} 35 / 65$; whereas sample $\mathrm{Cu} / \mathrm{Ce} 30 / 70$ reached almost $100 \%$ removal in the same time, but this sample is still experiencing rather strong dye adsorption. In conclusion, the increment of $\mathrm{Cu}$ in the $\mathrm{Cu} / \mathrm{Ce}$ samples diminishes the absorption and enhances the photodegradation of the Indigo Carmine. 


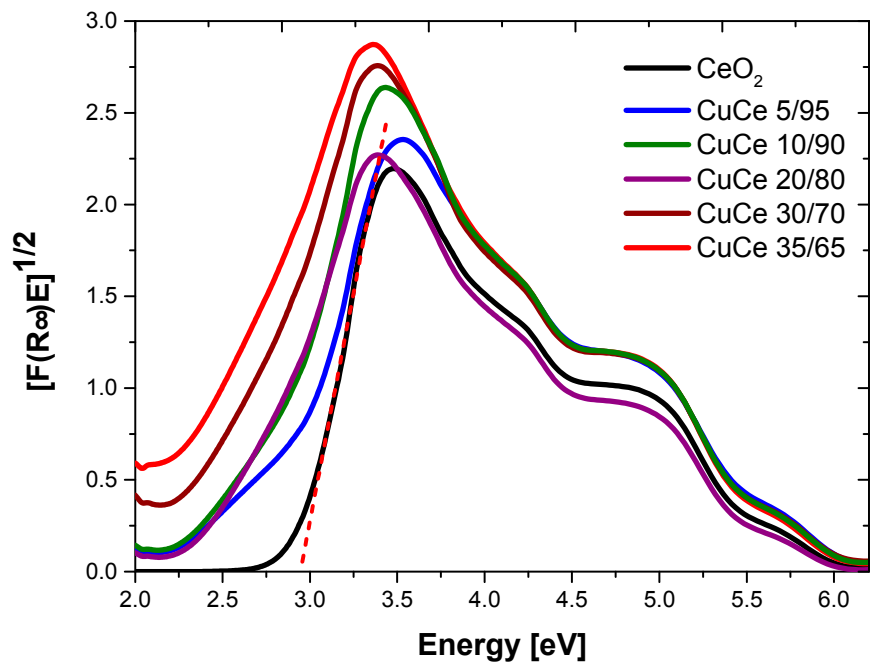

Figure 8. Kubelka Munk absorption spectra of non-calcined nanomaterials at different $\mathrm{Cu} / \mathrm{Ce}$ molar ratio.

Table 4. $E_{g}$ values for $\mathrm{Cu} / \mathrm{Ce}$ samples obtained by Kubelka Munk function.

\begin{tabular}{cc}
\hline Material & Band Gap (eV) \\
\hline $\mathrm{CeO}_{2}$ & 2.91 \\
$\mathrm{CuCe} \mathrm{5/95}$ & 2.85 \\
$\mathrm{CuCe} \mathrm{10/90}$ & 2.75 \\
$\mathrm{CuCe} \mathrm{20/80}$ & 2.67 \\
$\mathrm{CuCe} \mathrm{30/70}$ & 2.65 \\
$\mathrm{CuCe} \mathrm{35/65}$ & 2.27 \\
\hline
\end{tabular}

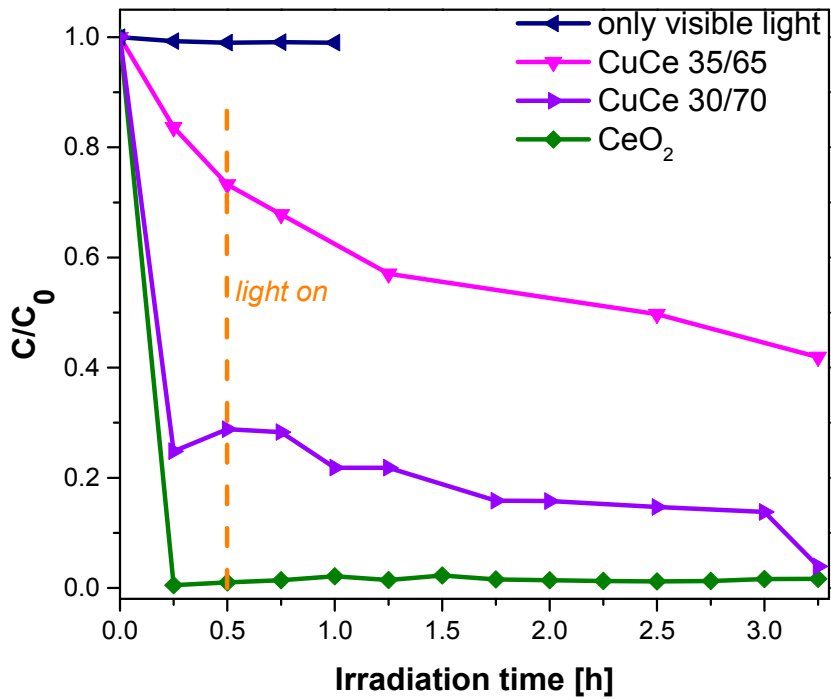

Figure 9. $\mathrm{C} / \mathrm{C}_{0}$ versus irradiation time for the degradation of indigo carmine using $\mathrm{CeO}_{2}, \mathrm{Cu} / \mathrm{Ce}$ $(30 / 70$ and $35 / 65))$ under visible light irradiation. 


\section{Discussion}

\subsection{Microemulsion Formation and Particle Synthesis}

The slight variation of temperature at which microemulsions were formed when the $\mathrm{Cu} / \mathrm{Ce}$ ratio was increased may be explained by a different interfacial activity of the $\mathrm{Cu}$ (II) and Ce (III) 2-ethylhexanoate precursors, affecting the hydrophilic-lipophilic balance of the surfactant placed at the $\mathrm{O} / \mathrm{W}$ interface to a different extent. This suggestion is in agreement with the findings of Oliveira et al. In their study, spectroscopic analysis was used to demonstrate that a similar precursor, cobalt (II) 2-ethylhexanoate doped in water/AOT/heptane W/O microemulsions, resides at the O/W interface [38]. In addition, our research group investigated the phase behavior of a water/surfactant/oil system very similar to the system used in the present study, in which cerium (III) 2-ethylhexanoate precursor was incorporated in the oil phase [31]. It was demonstrated that the presence of this precursor resulted in the modification of the $\mathrm{O} / \mathrm{W}$ microemulsion region in pseudo-ternary phase diagrams. The fact that higher temperature was needed for microemulsion formation as the concentration of Copper (II) precursor was increased may be explained as follows. Ce (III) precursor has three units of 2-ethylhexanoate complexing agent, whereas $\mathrm{Cu}$ (II) precursor has two units. Thus, it can be assumed that the steric effect is reduced with $\mathrm{Cu}$ (II) precursor leading to better packing at the oil/water interface (in a similar manner as Cobalt (II) 2-ethylhexanoate), as compared to the bulkier Ce (III) precursor. Thus, the hydrophilic-lipophilic balance is affected to a greater extent when the concentration of $\mathrm{Cu}$ (II) precursor is increased.

In any case, it was possible to carry out the reactions close to room temperature $\left(27-30{ }^{\circ} \mathrm{C}\right)$. A simple process approach such as the one presented in this investigation can be applied to further studies such as scaling up. Furthermore, the nonionic surfactant used is a low cost technical grade material which is biodegradable, and given that its solubility depends greatly on temperature further studies may permit its reuse.

Regarding the formation of $\mathrm{Cu} / \mathrm{Ce}$ mixed oxide nanoparticles in the $\mathrm{O} / \mathrm{W}$ microemulsions, due to the fact that the metal-organic precursors are dissolved in the oil phase, and the precipitating agent is soluble in the aqueous phase, the reaction should start at the oil/water interface, forming the first nuclei. Considering the small size of microemulsion droplets (in the order of $5 \mathrm{~nm}$, as characterized by dynamic light scattering), and the huge oil/water interfacial area, there is a great level of confinement for the reaction to occur, resulting in the formation of small nanoparticles with a great level of interaction at the nanoscale level between the two precursors, leading to highly homogeneous materials up to $\mathrm{Cu} / \mathrm{Ce}$ molar ratio $30 / 70$, as demonstrated by the different characterization techniques.

\subsection{Characterization of $\mathrm{Cu} / \mathrm{Ce}$ Oxide Nanoparticles}

HRTEM studies showed that rather small NPs were obtained: about 2-3 nm for non-calcined samples and about 5-7 nm for calcined samples. Homogeneity of materials below $\mathrm{Cu} / \mathrm{Ce}$ molar ratio 30/70 as shown by HRTEM, EDX, and XRD spectra may be attributed to the fact that the precursors are confined inside the microemulsion droplets at the nanometer level, leading to an increased synergy between the oxides. Furthermore, the increase of $\mathrm{Cu} / \mathrm{Ce}$ molar ratio promoted a decrease of crystallite size, which may suggest that either enrichment of $\mathrm{Cu}^{2+}$ on the surface of $\mathrm{CeO}_{2}$ or $\mathrm{Cu}^{2+}$ incorporated into the $\mathrm{CeO}_{2}$ lattice, inhibited the crystal growth of ceria. The ionic radius of $\mathrm{Cu}^{2+}(0.072 \mathrm{~nm})$ is smaller than $\mathrm{Ce}^{4+}(0.097 \mathrm{~nm})$ and $\mathrm{Ce}^{3+}(0.1143 \mathrm{~nm})$, thus, an increasing amount of $\mathrm{Cu}$ into the $\mathrm{CeO}_{2}$ lattice can lead to a reduction of its cell size [25]. However, incorporation of $\mathrm{Cu}$ into the cubic $\mathrm{CeO}_{2}$ lattice would also imply a shift in the position of the main reflection to higher $2 \theta$ values. Indeed, for non-calcined samples there appears to be a shift in the position of the main reflection to higher values; in contrast, for the calcined samples, this shift is rather small with respect to $\mathrm{CeO}_{2}\left(2 \theta=28.7^{\circ}\right.$ for $\mathrm{CeO}_{2}$ versus $28.74^{\circ}-28.77^{\circ}$ for calcined samples). Thus, the apparent larger shift in the non-calcined samples is more likely to be attributed to the large broadening of the reflections caused by the small size of the domains, which prevents an accurate positioning of the maximum. Furthermore, the fact that 
the agglomeration of the nanoparticles decreases as the $\mathrm{Cu}$ content increases (Figure 1), supports a change in the surface free energy of the nanoparticles, which could be ascribed to enrichment of $\mathrm{Cu}^{2+}$ on the surface, e.g., a good dispersion of $\mathrm{Cu}^{2+}$ ions onto $\mathrm{CeO}_{2}$ [7,39]. Although, partial substitution of $\mathrm{Ce}^{4+} / \mathrm{Ce}^{3+}$ by $\mathrm{Cu}^{2+}$ in the ceria lattice cannot be ruled out.

Even though in the $\mathrm{Cu} / \mathrm{Ce} 30 / 70$ non-calcined sample only small particles were observed by HRTEM and $\mathrm{CuO}$ phase was not detected by XRD, after calcination at 400 and $500{ }^{\circ} \mathrm{C}$ some excess monoclinic $\mathrm{CuO}$ phase was indeed detected by both techniques (Figure 5). Thus, it is inferred that $\mathrm{CuO}$ was formed initially as a very well dispersed secondary amorphous phase. Calcination caused phase segregation and crystallization of monoclinic $\mathrm{CuO}$ for this sample, whereas for the sample with $\mathrm{Cu} / \mathrm{Ce}$ molar ratio 20/80 no phase segregation of monoclinic $\mathrm{CuO}$ was observed even after calcination at $500{ }^{\circ} \mathrm{C}$. On the contrary, for the samples with $\mathrm{Cu} / \mathrm{Ce}$ molar ratio 35/65, 40/60, and 50/50, $\mathrm{Cu}^{2+}$ ions concentration was too high to remain completely well dispersed, and it partially segregated as $\mathrm{CuO}$ in the as-obtained samples. The fact that this segregated $\mathrm{CuO}$ was monoclinic even without calcination, evidences the strong interaction between $\mathrm{Cu}^{2+}$ ions and ceria in the mixed oxide synthesized by this method, that prevents its segregation as monoclinic $\mathrm{CuO}$ up to $\mathrm{Cu} / \mathrm{Ce}$ molar ratio 20/80 even after thermal treatment.

The Raman spectra indicated a slight shift towards lower wavenumber for the $\mathrm{F}_{2 \mathrm{~g}}$ Raman active mode of the $\mathrm{CeO}_{2}$ fluorite phase as the concentration of $\mathrm{Cu}$ was increased (Figure 6b), illustrating that the $\mathrm{CeO}_{2}$ fluorite-type lattice was distorted with the incorporation of $\mathrm{Cu}^{2+}$ ions into $\mathrm{CeO}_{2}$. On the other hand, the widths of the $\mathrm{F}_{2 \mathrm{~g}}$ bands are similar, due to very small and similar crystallite size obtained in all cases. For $\mathrm{CeO}_{2}$ in the present study, the characteristic and relatively intense $\mathrm{F}_{2 \mathrm{~g}}$ band, was centered at 452 and $455 \mathrm{~cm}^{-1}$ (non-calcined and calcined at $500{ }^{\circ} \mathrm{C}$, respectively). This is in agreement with the work by Spanier et al., who reported a Raman shift of $458 \mathrm{~cm}^{-1}$ for $\mathrm{CeO}_{2}$ nanoparticles of $6.1 \mathrm{~nm}$, and a general shift towards lower wavenumber as the particle size of $\mathrm{CeO}_{2}$ is decreased [40]. Thus, it is expected that smaller particles have a Raman shift towards lower wavenumber. According to Wang et al., the $\mathrm{F}_{2 \mathrm{~g}}$ band of a sample with 20 molar\% of $\mathrm{Cu}$ prepared using W/O microemulsions was centered at $457 \mathrm{~cm}^{-1}$, as compared to $\mathrm{CeO}_{2}$ synthesized by the same method which was centered at $463.5 \mathrm{~cm}^{-1}$ [41]. Thus, a shift of about $6 \mathrm{~cm}^{-1}$ was observed when the $\mathrm{Cu} / \mathrm{Ce}$ molar ratio was 20/80. In the present study, $\mathrm{Cu} / \mathrm{Ce}$ with molar ratio 20/80 was shifted to 446 and $447 \mathrm{~cm}^{-1}$ (as-obtained and calcined at $500{ }^{\circ} \mathrm{C}$, respectively). Thus, the shift was in the order of $6-8 \mathrm{~cm}^{-1}$. A similar shift was obtained for the sample with $\mathrm{Cu} / \mathrm{Ce}$ molar ratio 30/70. Therefore, the shift is comparable to the shift obtained in the investigation reported by Wang et al. [41], who interpreted this outcome to the incorporation of $\mathrm{Cu}$ into the $\mathrm{CeO}_{2}$ cubic lattice. Although, as mentioned previously, this should be accompanied by $\mathrm{Cu}^{2+}$ surface enrichment, since the XRD reflections presented a rather small shift [42]. In any case, given the small size of the $\mathrm{Cu} / \mathrm{Ce}$ mixed oxide nanoparticles, a very large percentage of the atoms must reside at these surface/subsurface locations.

As mentioned previously, the band at $500-650 \mathrm{~cm}^{-1}$ can be assigned to oxygen vacancies [36]. For $\mathrm{CeO}_{2}$, this is in agreement with the presence of an important amount of $\mathrm{Ce}^{3+}$, as already reported for $\mathrm{CeO}_{2}$ synthesized by the $\mathrm{O} / \mathrm{W}$ microemulsion method [43]. On the other hand, the increase in the intensity of this band in the $\mathrm{Cu} / \mathrm{Ce}$ mixed oxides may be attributed to the incorporation of $\mathrm{Cu}^{2+}$ ions into the ceria lattice, which must be accompanied by the generation of oxygen vacancies in order to keep the charge balance. A way to assess the relative oxygen vacancies in a comparative manner is to express the ratio of the area of the vacancies band $\left(\mathrm{A}_{600}\right)$ with respect to the area of the $\mathrm{F}_{2 \mathrm{~g}}$ band $\left(\mathrm{A}_{450}\right)$ [44]. For the samples calcined at $500{ }^{\circ} \mathrm{C}$, there was a steady increase in the $\mathrm{A}_{600} / \mathrm{A}_{450}$ ratio up to $\mathrm{Cu} / \mathrm{Ce}$ molar ratio 20/80, after which it leveled off (Figure 6c). This could be explained by the fact that for the $\mathrm{Cu} / \mathrm{Ce} 30 / 70$ sample calcined at $500{ }^{\circ} \mathrm{C}$ an important amount of $\mathrm{CuO}$ had phase-separated, leaving the $\mathrm{Cu} / \mathrm{Ce}$ mixed oxide with a composition similar to the $\mathrm{Cu} / \mathrm{Ce} 20 / 80$ sample. On the other hand, the as-obtained samples presented a rapid increase at $\mathrm{Cu} / \mathrm{Ce} 5 / 95$ as compared to $\mathrm{CeO}_{2}$, with little increase above this $\mathrm{Cu} / \mathrm{Ce}$ molar ratio. Thus, calcination induced an increase of oxygen vacancies 
as a function of $\mathrm{Cu}$ concentration, as compared to the as-obtained samples; this can be ascribed to the increased crystallinity, allowing for a better incorporation of $\mathrm{Cu}^{2+}$ into the $\mathrm{CeO}_{2}$ lattice.

Between 100-300 $\mathrm{cm}^{-1}$ there are some other bands which have not been usually reported in these $\mathrm{Cu} / \mathrm{Ce}$ mixed oxides. Samples $\mathrm{Cu} / \mathrm{Ce} 30 / 70$ (as-obtained and calcined at $500{ }^{\circ} \mathrm{C}$ ) present a small band centered at 272 and $280 \mathrm{~cm}^{-1}$ (respectively) which could be attributed to the one-phonon $\mathrm{A}_{1 \mathrm{~g}}$ mode of $\mathrm{CuO}$ [45]. This is in agreement with the results from XRD for the calcined sample; for the as-obtained sample $\mathrm{CuO}$ was not detected, so probably it was very well dispersed and/or in a concentration below the limits of the technique. The other small bands at around 180 and $250 \mathrm{~cm}^{-1}$, are probably also related to the oxygen vacancies, since these are also present in the $\mathrm{CeO}_{2}$ samples, and they follow the trends of the bands at $500-650 \mathrm{~cm}^{-1}$ [44].

A systematic study on the preparation of $\mathrm{Cu} / \mathrm{Ce}$ oxide nanoparticles at various $\mathrm{Cu} / \mathrm{Ce}$ molar ratios using the flame method was previously reported by Pati et al. [46]. They found that below $40 / 60 \mathrm{Cu} / \mathrm{Ce}$ molar ratio, crystalline $\mathrm{CuO}$ could not be detected by $\mathrm{XRD}$, however it was demonstrated by HRTEM that a core-shell structure was obtained, in which fluorite-type $\mathrm{CeO}_{2}$ formed the core and amorphous $\mathrm{CuO}$ formed the shell. Thus, even though the temperature of synthesis reached $1500{ }^{\circ} \mathrm{C}$ in the flame method, a mixed $\mathrm{Cu} / \mathrm{Ce}$ oxide phase was not obtained and the $\mathrm{CuO}$ phase was amorphous. In the present study, no clear evidence for a core-shell configuration was found by HRTEM, however the surface may be enriched with a thin layer of $\mathrm{Cu}^{2+}$ ions. For the higher concentrations of $\mathrm{Cu}$ $(\mathrm{Cu} / \mathrm{Ce}$ molar ratios 35/65, 40/60, and 50/50) HRTEM showed amorphous zones. Nonetheless, in our investigation it has been shown that if the $\mathrm{Cu} / \mathrm{Ce}$ ratio is high enough (35/65 and above), monoclinic $\mathrm{CuO}$ is formed, even at mild reaction conditions. Thus, the amorphous zones for samples with $\mathrm{Cu} / \mathrm{Ce}$ molar ratios 35/65, 40/60, and 50/50 are more likely to be formed by the mixed $\mathrm{Cu} / \mathrm{Ce}$ oxide.

It is worth noting that various configurations of $\mathrm{Cu} / \mathrm{Ce}$ oxide materials have been obtained depending on the preparation method, such as the core- $\mathrm{CeO}_{2} /$ shell- $\mathrm{CuO}$ mentioned above, as well as nanoparticles or films of mixed $\mathrm{Cu} / \mathrm{Ce}$ oxide in which $\mathrm{Cu}$ is either very well dispersed or incorporated into the $\mathrm{CeO}_{2}$ lattice $[39,41,47-51]$. However, the limit of $\mathrm{Cu}$ content that can be incorporated without forming an excess separate $\mathrm{CuO}$ phase depends strongly on the preparation method and reaction conditions. With the impregnation method, it was reported by Yang et al. that excess monoclinic $\mathrm{CuO}$ phase can be detected by XRD at $\mathrm{Cu} / \mathrm{Ce}$ molar ratio 5/95 [47]. In a similar investigation by Zheng et al., monoclinic $\mathrm{CuO}$ phase was detected from $10 / 90 \mathrm{Cu} / \mathrm{Ce}$ molar ratio by the impregnation method [48], although Tian et al. reported the incorporation of $\mathrm{Cu}$ up to a $15 / 85 \mathrm{Cu} / \mathrm{Ce}$ molar ratio using the same preparation method [49]. Using the urea precipitation-gelation method, it was possible to incorporate $\mathrm{Cu}$ up to a 15/85 Cu/Ce molar ratio, according to Kobayashi et al. [39]. Slusser et al. reported the formation of epitaxial films by the pulsed laser deposition technique, in which $\mathrm{Cu}$ was incorporated into the $\mathrm{CeO}_{2}$ lattice up to a $15 / 85 \mathrm{Cu} / \mathrm{Ce}$ molar ratio; higher $\mathrm{Cu}$ content was not reported [52]. By a modified citrate sol-gel method, monoclinic $\mathrm{CuO}$ phase was detected by $\mathrm{XRD}$ at 20/80 Cu/Ce molar ratio [50]. Fotopoulus et al. reported the synthesis of mixed $\mathrm{Cu} / \mathrm{Ce}$ oxide in which $\mathrm{Cu}$ was incorporated into the $\mathrm{CeO}_{2}$ lattice up to a $23 / 77 \mathrm{Cu} / \mathrm{Ce}$ molar ratio, or it was very well dispersed; the synthesis was carried out by a solvothermal method using oleylamine/TOPO mixtures at $350{ }^{\circ} \mathrm{C}$ [51]. Wang et al. reported that by the reverse microemulsion reaction method, only cubic fluorite-type ceria structure was observed for samples with up to $20 / 80 \mathrm{Cu} / \mathrm{Ce}$ molar ratio [41].

The experimental advantages of preparing mixed $\mathrm{Cu} / \mathrm{Ce}$ oxide nanoparticles by the $\mathrm{O} / \mathrm{W}$ microemulsion reaction method are the use of mild conditions (room temperature), lower concentration of solvents as compared to the solvothermal or W/O microemulsion methods, and the use of simple and inexpensive equipment. In addition, the homogeneity and confinement of the molecular mixture of $\mathrm{Cu} / \mathrm{Ce}$ precursors inside the microemulsion droplets during synthesis, and the narrow size distribution (low polydispersity) obtained, may promote a stronger synergistic effect between copper and ceria leading to an improved performance in catalysis such as in the Water-Gas Shift reaction and other catalytic processes [53]. 


\subsection{Magnetic Properties}

It was reported recently that certain transition metal-doped rare earth oxides such as $\mathrm{CeO}_{2}$ led to room temperature ferromagnetism [54-56]. Tiwari et al. reported that incorporation of cobalt into the $\mathrm{CeO}_{2}$ lattice resulted in room temperature ferromagnetism and high Curie Temperature [54]. Ferromagnetic behavior was also reported in $\mathrm{Ni}$ - and $\mathrm{Fe}-\mathrm{doped} \mathrm{CeO}_{2}[55,56]$. A significant debate exists about whether the observed properties are an intrinsic property of the material or an extrinsic property due to the preparation method, presence of impurities and so on. This controversy still remains intense since all the materials prepared as transition metal-doped $\mathrm{CeO}_{2}$ are magnetic even though a very small amount of the dopant is used [54-56]. In the present investigation, it was clearly observed that by incorporating non-magnetic $\mathrm{Cu}^{2+}$ ions into $\mathrm{CeO}_{2}$, the magnetization response was enhanced.

Slusser et al. [52] found unexpected ferromagnetic behavior in $\mathrm{Cu}$-doped $\mathrm{CeO}_{2}$ films prepared by a pulse laser deposition technique at room temperature. This magnetic behavior could not be detected for the same materials prepared in the $\mathrm{O} / \mathrm{W}$ microemulsion method. This difference in magnetic behavior may be related to the nanoparticle size difference or cation partition in the sample. Indeed, in the present study the nanoparticle size was $\sim 2-3 \mathrm{~nm}$ whereas in the study by Slusser et al., although no size detail was given, based on the resolution of XRD reflections, it can be inferred that the characteristic crystallite size was much larger.

\subsection{Optical Properties and Photocatalytic Activity}

In the literature, various values of $E_{\mathrm{g}}$ have been reported for $\mathrm{CeO}_{2}$ nanostructures, depending on the preparation method. Ho et al. [57] reported $E_{\mathrm{g}}$ values from 3.36 to 3.62 for mesoporous $\mathrm{CeO}_{2}$ nanostructures with different morpohologies (rod shape and spindle-like), synthesized by polyol method. In contrast, by the precipitation method higher $E_{\mathrm{g}}(3.56$ to $3.71 \mathrm{eV})$ were reported for $\mathrm{CeO}_{2}$ [58]. Masui et al. reported slightly lower $E_{\mathrm{g}}$ values ( 3.38 and $3.44 \mathrm{eV}$ ) when $\mathrm{CeO}_{2} \mathrm{NPs}$ with sizes between 2.6 and $3.4 \mathrm{~nm}$ were prepared in reverse micelles [59]. It was reported by Patsalas et al. that the the red shifting in the band gap of $\mathrm{CeO}_{2}$ is due to an increase in the concentration of $\mathrm{Ce}^{3+}$ on the grain boundaries; the reduction of the band gap increases with increasing $\mathrm{Ce}^{3+}$ concentration and its corresponding increase in oxygen vacancies [60]. Thus, the relatively low $E_{\mathrm{g}}$ value obtained for $\mathrm{CeO}_{2}$ in the present study of $2.9 \mathrm{eV}$ could be related to an important contribution from oxygen vacancies (as indicated from the Raman results), which is accompanied by a high concentration of $\mathrm{Ce}^{3+}$ as previously reported for $\mathrm{CeO}_{2}$ obtained in $\mathrm{O} / \mathrm{W}$ microemulsions [43].

On the other hand, reports on the $E_{\mathrm{g}}$ values of $\mathrm{Cu} / \mathrm{Ce}$ oxides are rare. In our study, it was shown by XRD and HRTEM techniques that the obtained $\mathrm{Cu} / \mathrm{Ce}$ mixed oxide nanoparticles had a slightly smaller size as the concentration of $\mathrm{Cu}$ was increased. According to the study by Tsunekawa et al., the $E_{\mathrm{g}}$ values of $\mathrm{CeO}_{2}$ nanoparticles should increase as the particle size is decreased, due to the electron confinement effect [61]. However, in this investigation, the incorporation of $\mathrm{Cu}$ into the cubic $\mathrm{CeO}_{2}$ lattice promoted a general decrease of $E_{\mathrm{g}}$ of $\mathrm{Cu} / \mathrm{Ce}$ mixed oxide nanoparticles compared to $\mathrm{CeO}_{2}$ nanoparticles. Slusser et al. reported that the $E_{\mathrm{g}}$ values decreased as the concentration of $\mathrm{Cu}$ was increased for $\mathrm{Cu} / \mathrm{Ce}$ nanostructured films [52]. However, the values in that study were 3.45, 3.43, and $3.39 \mathrm{eV}$ for samples containing 0,3 and 15 atomic $\%$ of $\mathrm{Cu}$. The synthesis of $\mathrm{CeO}_{2}$ and $\mathrm{Cu} / \mathrm{Ce}$ mixed oxide NPs using Oil-in-Water microemulsions as confined reaction media led to NPs possessing even lower $E_{\mathrm{g}}$ values which may be of high interest in optoelectronics, photovoltaic, and photocatalytic applications, since $E_{\mathrm{g}}$ values lower than $3 \mathrm{eV}$ implies that the material may be photoactive under visible light irradiation.

The photocatalytic activity was confirmed in this investigation for the photodegradation of Indigo Carmine, which reached $60 \%$ after $3 \mathrm{~h}$ of irradiation with visible light for sample $\mathrm{Cu} / \mathrm{Ce}$ $(35 / 65)$ and almost $100 \%$ of photodegradation was reached when sample $\mathrm{Cu} / \mathrm{Ce}(30 / 70)$ was used as photocatalyst. However, in this last case the dye is at least partially adsorbed by the sample due to the high amount of Ce. On the other hand, Indigo Carmine degradation is commonly due to the formation of several intermediates as reported in other works; it means that the formation of intermediates and 
the degradation of the chromophore group is a common step in the photodegradation process of this dye [62]. Therefore, in our case, the degradation of Indigo Carmine by using $\mathrm{Cu} / \mathrm{Ce}$ with molar ratios $30 / 70$ and $35 / 65$ could be due to the sulphate ion separation and bonds breaking and arranging to form compounds with nitro groups and finally obtain carboxylic acids [62]. In any case, it was demonstrated that both $\mathrm{CeO}_{2}$ and the mixed $\mathrm{Cu} / \mathrm{Ce}$ oxides synthesized in $\mathrm{O} / \mathrm{W}$ microemulsions, can be used for the remediation of water to remove contaminants such as certain dyes, either by photocatalytic degradation or by adsorption, or both.

It is worth mentioning that a previous report from Torres-Martinez on the photodegradation of Indigo Carmine using $\mathrm{Sm}_{2} \mathrm{FeTaO}_{7}$ photocatalyst under solar light resulted in better performance when using $\mathrm{CuO}$ as cocatalyst, which was ascribed to $\mathrm{CuO}$ acting as an electron trap, decreasing electron-hole pair recombination rates [63]. This suggests a double advantage of having a well dispersed $\mathrm{CuO}$ phase as in the $\mathrm{Cu} / \mathrm{Ce}$ oxide system reported in this investigation, or even an excess monoclinic $\mathrm{CuO}$ phase, for improving the photocatalytic performance of $\mathrm{CeO}_{2}$. On one hand, the red shift of the $E_{\mathrm{g}}$ value permits its photocatalytic activation under visible or solar light radiation, and on the other hand, the presence of $\mathrm{CuO}$ as cocatalyst acts as an electron trap.

\section{Materials and Methods}

\subsection{Materials}

Synperonic ${ }^{\circledR}$ 91/5 (Polyoxyethylene (5) C9-C11 alcohol, HLB $=12$, Cloud point $\mathrm{T}=36^{\circ} \mathrm{C}$ ) was kindly obtained from Croda. Cerium (III) 2-ethylhexanoate (Ce-2EH, solid) was purchased from Sigma Aldrich, Copper (II) 2-ethylhexanoate (Cu-2EH, ca 98\%) was purchased from Alfa Aesar. Isooctane (Suprasolv, for gas chromatography, $99 \% \mathrm{~min}$ ) was from Honeywell Burdick \& Jackson. Isopropanol $(99.5 \%)$ and sodium hydroxide $(\mathrm{NaOH}$, pellets, $98.4 \%)$ were purchased from J.T. Baker. Ethanol $(99 \%)$ was purchased from CTR Scientific. Deionized water with a resistivity of $18.2 \mathrm{M} \Omega \mathrm{cm}^{-1}$ was obtained from a Millipore system.

\subsection{Preparation of NPs by the O/W Microemulsion Reaction Method}

Microemulsions are well known as thermodynamic stable systems containing water, oil and surfactant leading to a transparent and fluid isotropic solution. The organometallic precursors (Ce-2EH and $\mathrm{Cu}-2 \mathrm{EH}$ were dissolved in isooctane composing the oil phase (which had a total metal concentration of $0.105 \mathrm{~mol}$ per kg of solution). Then, deionized water, Synperonic ${ }^{\circledR} 91 / 5$ and the oil phase (containing the precursors) were mixed. The composition of the microemulsion selected was: $64.5 \mathrm{wt} \%$ water, $21.5 \mathrm{wt} \%$ Synperonic ${ }^{\circledR} 91 / 5$, and $14 \mathrm{wt} \%$ oil. The mixture was magnetically stirred at the appropriate microemulsion temperature (Table 1) until a homogeneous, transparent and fluid isotropic single phase was obtained. In order to form the mixed oxide nanoparticles, an aqueous solution of $\mathrm{NaOH}(2.5 \mathrm{M})$ was added under vigorous stirring until $\mathrm{pH} 12$ was reached, whilst the microemulsion temperature was kept constant. The reaction mixture was kept overnight at constant stirring, followed by centrifugation. The nanoparticles were washed with ethanol and water $(v / v=1 / 1)$ until a neutral $\mathrm{pH}$ was reached in the washing liquors. The solids were dried at $70{ }^{\circ} \mathrm{C}$ over 2 days, and ground using an agate pestle and mortar. The synthesized materials were $\mathrm{CeO}_{2}$ and $\mathrm{Cu}_{x} \mathrm{Ce}_{1-x} \mathrm{O}_{2-\delta}$ $(x=0.05,0.10,0.20,0.30,0.35,0.40,0.50)$. Some materials were calcined with a temperature ramp of $5{ }^{\circ} \mathrm{C} / \mathrm{min}$ and a dwelling time of $2 \mathrm{~h}$; the calcination temperatures were $400{ }^{\circ} \mathrm{C}$ or $500^{\circ} \mathrm{C}$.

\subsection{Characterization of NPS}

Particle size and morphology were investigated using a High-Resolution Transmission Electron Microscope (HRTEM) JEOL JEM-2200FS, operated at $200 \mathrm{kV}$, and point resolution of $0.1 \mathrm{~nm}$ in TEM mode. Preparation of TEM grids was carried out by mixing a small amount of powder with isopropanol $(2 \mathrm{~mL})$ followed by sonication, and depositing a drop of this dispersion onto a formvar/carbon copper grid. The crystal structure was analyzed by X-ray diffraction (XRD (PANalytical, Almelo, The 
Netherlands)) using a PANalytical Empyrean diffractometer with $\mathrm{CuK}_{\alpha}$ radiation in continuous scan mode from $10^{\circ}$ to $80^{\circ}$ of $2 \theta$ with 0.001 step size. Fullprof Suite software $(2007$, Grenoble, France) was used for data treatment. The crystallite size was estimated by X-ray Diffraction with the Scherrer equation using the broadening of the reflection with the highest intensity $\left(2 \theta=28.7^{\circ}\right)$. Raman spectroscopy was carried out using a micro-Raman LabRAM HR Evolution from Horiba (Kyoto, Japan), coupled to an Olympus BX-4 microscope. The wavelength used to excite the sample was $632.8 \mathrm{~nm}$, which was provided with a He-Ne laser, the power was kept at $17 \mathrm{~mW}$, the resolution was $1 \mathrm{~cm}^{-1}$ and the diffraction grating was $600 \mathrm{~L} / \mathrm{mm}$; all measurements were performed at room temperature. The power of the laser was varied between $5 \%$ and $10 \%$, depending on the sample.

\subsection{Magnetic Properties, Optical Properties and Photocatalytic Performance}

The magnetic properties of the obtained nanomaterials were assessed using superconducting quantum interface device (SQUID) magnetometer Quantum Design MPMS XL. The energy band gap $\left(E_{\mathrm{g}}\right)$ of the powders was determined by the Kubelka-Munk function using a UV-vis spectrophotometer (Lambda 35 Perkin Elmer Corporation) coupled with an integrating sphere. The photocatalytic degradation of Indigo Carmine was carry out using $200 \mathrm{~mL}$ of a 20 ppm solution of the dye; $0.2 \mathrm{~g}$ of the photocatalyst were used for each experiment. Irradiation was carried out with a visible light lamp (Xenon lamp HID, 3200 Lumen, 6000 K Onof, Guangzhou, China). The development of the photocatalytic reaction was conducted by UV-vis analysis using a Lambda 35 Perkin Elmer Corporation spectrophotometer; samples were taken every 15 min during $180 \mathrm{~min}$. Before turning on the Xenon lamp, $30 \mathrm{~min}$ in the dark were allowed for adsorption equilibria. The photolysis experiment was carried out in the same way, except that no photocatalyst was added.

\section{Conclusions}

Mixed $\mathrm{Cu} / \mathrm{Ce}$ oxide nanoparticles (below $\mathrm{Cu} / \mathrm{Ce}$ molar ratio 30/70) and mixtures of oxides (above this content) were prepared using the oil-in-water microemulsion reaction method under mild conditions. Nanoparticle size of mixed $\mathrm{Cu} / \mathrm{Ce}$ oxide was in the order of 2-3 nm with a low polydispersity. However, calcination above $400{ }^{\circ} \mathrm{C}$ showed clearly the presence of a minor $\mathrm{CuO}$ phase for samples with $\mathrm{Cu}$ content equal or larger than $30 \%$, evidencing the formation of mixed $\mathrm{Cu} / \mathrm{Ce}$ oxide as a major phase and a minor phase of $\mathrm{CuO}$ nanotapes with a monoclinic crystal structure. Evidence from characterization suggests a contribution from $\mathrm{Cu}^{2+}$ surface enrichment, ascribed to the lack of a significant shift in the XRD reflections and lower agglomeration in the mixed oxide; however, the shift in the signal corresponding to the $\mathrm{F}_{2 \mathrm{~g}}$ Raman active mode of the $\mathrm{CeO}_{2}$ fluorite phase and the increase of the Raman band ascribed to oxygen vacancies, suggest at least partial incorporation of $\mathrm{Cu}^{2+}$ into the $\mathrm{CeO}_{2}$ lattice. Nanoparticle characteristics were modulated by the variation of $\mathrm{Cu} / \mathrm{Ce}$ molar ratio in the $\mathrm{O} / \mathrm{W}$ microemulsion system. By incorporating $\mathrm{Cu}$ into $\mathrm{CeO}_{2}$, the magnetic properties could be tuned from diamagnetic to paramagnetic behavior. Moreover, the band gap $\left(E_{\mathrm{g}}\right)$ values of these nanomaterials were tuned and decreased as a function of $\mathrm{Cu} / \mathrm{Ce}$ ratio. These results are also

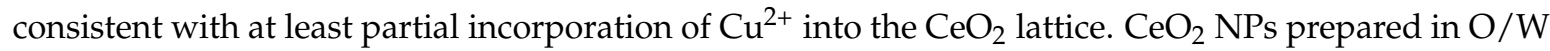
microemulsions possessed a lower $E_{\mathrm{g}}(2.9 \mathrm{eV})$ than those prepared using other methods as reported in literature. The obtained $E_{\mathrm{g}}$ values imply that both $\mathrm{CeO}_{2}$ and $\mathrm{Cu} / \mathrm{Ce}$ oxides may be photoactive under visible light. Indeed, it was shown for the first time that $\mathrm{Cu} / \mathrm{Ce}$ oxide nanoparticles are active as photocatalyst for the degradation of Indigo Carmine dye using visible light irradiation. These properties may promote their use as promising materials in photocatalytic, optoelectronic, photovoltaic, and fuel cells applications, in addition to their more common use as catalysts in the Water Gas Shift reaction. The usefulness of the $\mathrm{O} / \mathrm{W}$ microemulsion reaction method for the synthesis of homogeneous mixed oxides has been demonstrated.

Supplementary Materials: The following are available online at www.mdpi.com/1996-1944/9/6/480/s1. 
Acknowledgments: C.S. and K.P.B. acknowledge financial support from MINECO (grant number CTQ2011-29336-C03-01), Generalitat de Catalunya (AGAUR, grant number 2009SGR-961). M.S.D. is grateful to CONACYT (CB project grant number CB2011/166649). M.S.D. and I.J.R. are grateful to CONACYT (Proyecto Redes Temáticas No. 194451). We acknowledge NaNoTeCh, the National Nanotechnology Laboratory of Mexico, for HRTEM/STEM measurements; Francisco Enrique Longoria (CIMAV, S.C.) for XRD and Raman measurements and assistance.

Author Contributions: Kelly Pemartin-Biernath and Andrea V. Vela-González carried out synthesis of the materials and characterizations. Maira B. Moreno-Trejo and Iván E. Castañeda-Reyna carried out photocatalysis and diffuse reflectance. César Leyva-Porras performed HRTEM characterization. Margarita Sánchez-Domínguez, Conxita Solans and Isaías Juárez-Ramírez conceived and designed the experiments, and wrote the paper.

Conflicts of Interest: The authors declare no conflict of interest.

\section{References}

1. Mogensen, M.; Sammes, N.M.; Tompsett, G.A. Physical, chemical and electrochemical properties of pure and doped ceria. Solid State Ion. 2000, 129, 63-94. [CrossRef]

2. Imanaka, N.; Masui, T.; Hirai, H.; Adachi, G. Amorphous cerium-titanium solid solution phosphate as a novel family of band gap tunable sunscreen materials. Chem. Mater. 2003, 15, 2289-2291. [CrossRef]

3. Kakuta, N.; Morishima, N.; Kotobuki, M.; Iwase, T.; Mizushima, T.; Sato, Y.; Matsuura, S. Oxygen storage capacity (OSC) of aged $\mathrm{Pt} / \mathrm{CeO}_{2} / \mathrm{Al}_{2} \mathrm{O}_{3}$ catalysts: Roles of $\mathrm{Pt}$ and $\mathrm{CeO}_{2}$ supported on $\mathrm{Al}_{2} \mathrm{O}_{3}$. Appl. Surf. Sci. 1997, 121, 408-412. [CrossRef]

4. Lira-Cantu, M.; Krebs, F.C. Hybrid solar cells based on MEH-PPV and thin film semiconductor oxides $\left(\mathrm{TiO}_{2}\right.$, $\mathrm{Nb}_{2} \mathrm{O}_{5}, \mathrm{ZnO}, \mathrm{CeO}_{2}$ and $\mathrm{CeO}_{2}-\mathrm{TiO}_{2}$ ): Performance improvement during long-time irradiation. Sol. Energy Mater. Sol. Cells 2006, 90, 2076-2086. [CrossRef]

5. Morshed, A.; Moussa, M.E.; Bedair, S.M.; Leonard, R.; Liu, S.X.; El-Masry, N. Violet/blue emission from epitaxial cerium oxide films on silicon substrates. Appl. Phys. Lett. 1997, 70, 1647-1649. [CrossRef]

6. Wen, B.; He, M. Study of the Cu-Ce Synergism for $\mathrm{NO}$ Reduction with $\mathrm{CO}$ in the Presence of $\mathrm{O}_{2}, \mathrm{H}_{2} \mathrm{O}$ and $\mathrm{SO}_{2}$ in FCC Operation. Appl. Catal. B Environ. 2002, 37, 75-82. [CrossRef]

7. Bera, P.; Aruna, S.T.; Patil, K.C.; Hegde, M.S. Studies on $\mathrm{Cu} / \mathrm{CeO}_{2}$ : A new NO reduction catalyst. J. Catal. 1999, 186, 36-44. [CrossRef]

8. Liu, W.; Flytzani-Stephanopoulos, M. Transition metal-promoted oxidation catalysis by fluorite oxides: A study of $\mathrm{CO}$ oxidation over $\mathrm{Cu} \mathrm{CeO}_{2}$. Chem. Eng. J. Biochem. Eng. J. 1996, 64, 283-294. [CrossRef]

9. Pradhan, S.; Reddy, A.S.; Devi, R.N.; Chilukuri, S. Copper-based catalysts for water gas shift reaction: Influence of support on their catalytic activity. Catal. Today 2009, 141, 72-76. [CrossRef]

10. Liu, G.; Rodriguez, J.A.; Chang, Z.; Hrbek, J. Adsorption and reaction of $\mathrm{SO}_{2}$ on model Ce1-x Zr x O 2 (111) catalysts. J. Phys. Chem. B 2004, 108, 2931-2938. [CrossRef]

11. Overbury, S.H.; Mullins, D.R.; Trovarelli, A. Ceria surfaces and films for model catalytic studies using surface analysis techniques. Catal. Sci. Ser. 2002, 2, 311-337.

12. Fornasiero, P.; Balducci, G.; Di Monte, R.; Kaspar, J.; Sergo, V.; Gubitosa, G.; Ferrero, A.; Graziani, M. Modification of the redox behaviour of $\mathrm{CeO} 2$ induced by structural doping with $\mathrm{ZrO}_{2}$. J. Catal. 1996, 164, 173-183. [CrossRef]

13. Rodriguez, J.A. Electronic and chemical properties of mixed-metal oxides: Basic principles for the design of DeNO $x$ and DeSO x catalysts. Catal. Today 2003, 85, 177-192. [CrossRef]

14. Mariño, F.; Baronetti, G.; Laborde, M.; Bion, N.; Le Valant, A.; Epron, F.; Duprez, D. Optimized CuO-CeO 2 catalysts for COPROX reaction. Int. J. Hydrog. Energy 2008, 33, 1345-1353. [CrossRef]

15. Chowdhuri, A.; Gupta, V.; Sreenivas, K.; Kumar, R.; Mozumdar, S.; Patanjali, P.K. Response speed of $\mathrm{SnO}_{2}$-based $\mathrm{H}_{2} \mathrm{~S}$ gas sensors with $\mathrm{CuO}$ nanoparticles. Appl. Phys. Lett. 2004, 84, 1180-1182. [CrossRef]

16. Uzunoglu, A.; Stanciu, L.A. Novel $\mathrm{CeO}_{2}-\mathrm{CuO}$-decorated Enzymatic Lactate Biosensors Operating in Low Oxygen Environments. Anal. Chim. Acta 2016, 909, 121-128. [CrossRef] [PubMed]

17. Zhang, D.-W.; Yi, T.-H.; Chen, C.-H. Cu nanoparticles derived from $\mathrm{CuO}$ electrodes in lithium cells. Nanotechnology 2005, 16, 2338. [CrossRef] [PubMed]

18. Lake, B.; Rønnow, H.M.; Christensen, N.B.; Aeppli, G.; Lefmann, K.; McMorrow, D.F.; Vorderwisch, P.; Smeibidl, P.; Mangkorntong, N.; Sasagawa, T.; et al. Antiferromagnetic order induced by an applied magnetic field in a high-temperature superconductor. Nature 2002, 415, 299-302. [CrossRef] [PubMed] 
19. Kumar, S.K.; Murugesa, S.; Suresh, S.; Raj, S.P. Nanostructured CuO thin films prepared through sputtering for solar selective absorbers. J. Sol. Energy 2013, 2013, 147270.

20. Hsieh, C.-T.; Chen, J.-M.; Lin, H.-H.; Shih, H.-C. Field emission from various CuO nanostructures. Appl. Phys. Lett. 2003, 83, 3383-3385. [CrossRef]

21. Jammi, S.; Sakthivel, S.; Rout, L.; Mukherjee, T.; Mandal, S.; Mitra, R.; Saha, P.; Punniyamurthy, T. CuO nanoparticles catalyzed $\mathrm{C}-\mathrm{N}, \mathrm{C}-\mathrm{O}$, and $\mathrm{C}-\mathrm{S}$ cross-coupling reactions: Scope and mechanism. J. Org. Chem. 2009, 74, 1971-1976. [CrossRef] [PubMed]

22. Caputo, T.; Lisi, L.; Pirone, R.; Russo, G. On the role of redox properties of $\mathrm{CuO} / \mathrm{CeO}_{2}$ catalysts in the preferential oxidation of CO in H 2-rich gases. Appl. Catal. A Gen. 2008, 348, 42-53. [CrossRef]

23. Martínez-Arias, A.; Fernández-García, M.; Gálvez, O.; Coronado, J.M.; Anderson, J.A.; Conesa, J.C.; Soria, J.; Munuera, G. Comparative study on redox properties and catalytic behavior for $\mathrm{CO}$ oxidation of $\mathrm{CuO} / \mathrm{CeO}_{2}$ and $\mathrm{CuO} / \mathrm{ZrCeO}_{4}$ catalysts. J. Catal. 2000, 195, 207-216. [CrossRef]

24. Zhu, P.; Li, J.; Huang, Q.; Yan, S.; Liu, M.; Zhou, R. High performance CuO-CeO 2 catalysts for selective oxidation of $\mathrm{CO}$ in excess hydrogen: Effect of hydrothermal preparation conditions. J. Nat. Gas Chem. 2009, 18, 346-353. [CrossRef]

25. Szabová, L.; Skála, T.; Matolínová, I.; Fabris, S.; Camellone, M.F.; Matolín, V. Copper-ceria interaction: A combined photoemission and DFT study. Appl. Surf. Sci. 2013, 267, 12-16. [CrossRef]

26. Gurbani, A.; Ayastuy, J.L.; González-Marcos, M.P.; Gutiérrez-Ortiz, M.A. CuO-CeO 2 catalysts synthesized by various methods: Comparative study of redox properties. Int. J. Hydrog. Energy 2010, 35, 11582-11590. [CrossRef]

27. Sanchez-Dominguez, M.; Boutonnet, M.; Solans, C. A novel approach to metal and metal oxide nanoparticle synthesis: The oil-in-water microemulsion reaction method. J. Nanopart. Res. 2009, 11, 1823-1829. [CrossRef]

28. Boutonnet, M.; Kizling, J.; Stenius, P.; Maire, G. The preparation of monodisperse colloidal metal particles from microemulsions. Colloids Surf. 1982, 5, 209-225. [CrossRef]

29. Lopez-Quintela, M.A. Synthesis of nanomaterials in microemulsions: Formation mechanisms and growth control. Curr. Opin. Colloid Interface Sci. 2003, 8, 137-144. [CrossRef]

30. López-Quintela, M.A.; Tojo, C.; Blanco, M.C.; García Rio, L.; Leis, J.R. Microemulsion dynamics and reactions in microemulsions. Curr. Opin. Colloid Interface Sci. 2004, 9, 264-278. [CrossRef]

31. Sanchez-Dominguez, M.; Pemartin, K.; Boutonnet, M. Preparation of inorganic nanoparticles in oil-in-water microemulsions: A soft and versatile approach. Curr. Opin. Colloid Interface Sci. 2012, 17, 297-305. [CrossRef]

32. Margarita, S.-D.; Pemartin, K.; Solans, C.; Boutonnet, M. Oil-in-Water Microemulsions for the Synthesis of Nanocrystalline, Mesoporous and Ultrafine $\mathrm{CeO}_{2}$ Powders. In Colloid and Interface Chemistry for Nanotechnology; CRC Press: Boca Raton, FL, USA, 2013; pp. 177-197.

33. Keramidas, V.G.; White, W.B. Raman spectra of oxides with the fluorite structure. J. Chem. Phys. 1973, 59, 1561-1562. [CrossRef]

34. Reddy, B.M.; Khan, A.; Lakshmanan, P.; Aouine, M.; Loridant, S.; Volta, J.-C. Structural characterization of nanosized $\mathrm{CeO}_{2}-\mathrm{SiO}_{2}, \mathrm{CeO}_{2}-\mathrm{TiO}_{2}$, and $\mathrm{CeO}_{2}-\mathrm{ZrO}_{2}$ catalysts by XRD, Raman, and HREM techniques. J. Phys. Chem. B 2005, 109, 3355-3363. [CrossRef] [PubMed]

35. Reddy, B.M.; Khan, A.; Yamada, Y.; Kobayashi, T.; Loridant, S.; Volta, J.-C. Structural characterization of $\mathrm{CeO}_{2}-\mathrm{MO}_{2}\left(\mathrm{M}=\mathrm{Si}^{4+}, \mathrm{Ti}^{4+}\right.$, and $\left.\mathrm{Zr}^{4+}\right)$ mixed oxides by Raman spectroscopy, X-ray photoelectron spectroscopy, and other techniques. J. Phys. Chem. B 2003, 107, 11475-11484. [CrossRef]

36. McBride, J.; Hass, K.C.; Poindexter, B.D.; Weber, W.H. Raman and X-ray studies of $\mathrm{Ce}_{1}-\mathrm{xRExO}_{2}-\mathrm{y}$, where $\mathrm{RE}=\mathrm{La}, \mathrm{Pr}, \mathrm{Nd}, \mathrm{Eu}, \mathrm{Gd}$, and Tb. J. Appl. Phys. 1994, 76, 2435-2441. [CrossRef]

37. Kubelka, P. Ein beitrag zur optik der farban striche. Z Tech. Phys. 1931, 12, 593-603.

38. De Oliveira, R.J.; Brown, P.; Correia, G.B.; Rogers, S.E.; Heenan, R.; Grillo, I.; Galembeck, A.; Eastoe, J. Photoreactive surfactants: A facile and clean route to oxide and metal nanoparticles in reverse micelles. Langmuir 2011, 27, 9277-9284. [CrossRef] [PubMed]

39. Kobayashi, M.; Flytzani-Stephanopoulos, M. Reduction and sulfidation kinetics of cerium oxide and Cu-modified cerium oxide. Ind. Eng. Chem. Res. 2002, 41, 3115-3123. [CrossRef]

40. Spanier, J.E.; Robinson, R.D.; Zhang, F.; Chan, S.-W.; Herman, I.P. Size-dependent properties of $\mathrm{CeO}_{2}-\mathrm{y}$ nanoparticles as studied by Raman scattering. Phys. Rev. B 2001, 64, 245407. [CrossRef] 
41. Wang, X.; Rodriguez, J.A.; Hanson, J.C.; Gamarra, D.; Martínez-Arias, A.; Ferández-García, M. Unusual Physical and Chemical Properties of $\mathrm{Cu}$ in $\mathrm{Ce}_{1-\mathrm{x}} \mathrm{Cu}_{\mathrm{x}} \mathrm{O}_{2}$ Oxides. J. Phys. Chem. B 2005, 109, 19595-19603. [CrossRef] [PubMed]

42. Martínez-Arias, A.; Hungría, A.B.; Fernández-García, M.; Conesa, J.C.; Munuera, G. Interfacial redox processes under $\mathrm{CO} / \mathrm{O}_{2}$ in a nanoceria-supported copper oxide catalyst. J. Phys. Chem. B 2004, 108, 17983-17991. [CrossRef]

43. Sanchez-Dominguez, M.; Liotta, L.F.; Di Carlo, G.; Pantaleo, G.; Venezia, A.M.; Solans, C.; Boutonnet, M. Synthesis of $\mathrm{CeO}_{2}, \mathrm{ZrO}_{2}, \mathrm{Ce} 0.5 \mathrm{Zr} 0.5 \mathrm{O}_{2}$, and $\mathrm{TiO}_{2}$ nanoparticles by a novel oil-in-water microemulsion reaction method and their use as catalyst support for CO oxidation. Catal. Today 2010, 158, 35-43. [CrossRef]

44. Pu, Z.-Y.; Lu, J.-Q.; Luo, M.F.; Xie, Y.L. Study of oxygen vacancies in Ce0. 9Pr0. $1 \mathrm{O}_{2-\delta}$ solid solution by in situ X-ray diffraction and in situ Raman spectroscopy. J. Phys. Chem. C 2007, 111, 18695-18702. [CrossRef]

45. Wang, W.; Zhou, Q.; Fei, X.; He, Y.; Zhang, P.; Zhang, G.; Peng, L.; Xie, W. Synthesis of CuO nano-and micro-structures and their Raman spectroscopic studies. CrystEngComm 2010, 12, 2232-2237. [CrossRef]

46. Pati, R.K.; Lee, I.C.; Hou, S.; Akhuemonkhan, O.; Gaskell, K.J.; Wang, Q.; Frenkel, Al.; Chu, D.; Salamanca-Riba, L.G.; Ehrman, S.H. Flame Synthesis of Nanosized $\mathrm{Cu}-\mathrm{Ce}-\mathrm{O}, \mathrm{Ni}-\mathrm{Ce}-\mathrm{O}$, and $\mathrm{Fe}-\mathrm{Ce}-\mathrm{O}$ Catalysts for the Water-Gas Shift (WGS) Reaction. ACS Appl. Mater. Interfaces 2009, 1, 2624-2635. [CrossRef] [PubMed]

47. Yang, W.; Li, D.; Xu, D.; Wang, X. Effect of $\mathrm{CeO}_{2}$ preparation method and $\mathrm{Cu}$ loading on $\mathrm{CuO} / \mathrm{CeO}_{2}$ catalysts for methane combustion. J. Nat. Gas Chem. 2009, 18, 458-466. [CrossRef]

48. Zheng, X.-C.; Wu, S.-H.; Wang, S.-P.; Wang, S.-R.; Zhang, S.-M.; Huang, W.-P. The preparation and catalytic behavior of copper-cerium oxide catalysts for low-temperature carbon monoxide oxidation. Appl. Catal. A Gen. 2005, 283, 217-223. [CrossRef]

49. Tian, J.-J.; Na, W.; Wang, H.; Gao, W.-G. Preparation and characterization of Cu-doped mesoporous $\mathrm{CeO}_{2}$ for CO oxidation. J. Cent. South Univ. 2014, 21, 482-486. [CrossRef]

50. Luo, M.-F.; Song, Y.-P.; Lu, J.-Q.; Wang, X.-Y.; Pu, Z.-Y. Identification of CuO species in high surface area $\mathrm{CuO}-\mathrm{CeO}_{2}$ catalysts and their catalytic activities for CO oxidation. J. Phys. Chem. C 2007, 111, 12686-12692. [CrossRef]

51. Fotopoulos, A.; Arvanitidis, J.; Christofilos, D.; Papaggelis, K.; Kalyva, M.; Triantafyllidis, K.; Niarchos, D.; Boukos, N.; Basina, G.; Tzitzios, V. One pot synthesis and characterization of ultra fine $\mathrm{CeO}_{2}$ and $\mathrm{Cu} / \mathrm{CeO}_{2}$ nanoparticles. Application for low temperature CO oxidation. J. Nanosci. Nanotechnol. 2011, 11, 8593-8598. [CrossRef] [PubMed]

52. Slusser, P.; Kumar, D.; Tiwari, A. Unexpected magnetic behavior of Cu-doped $\mathrm{CeO}_{2}$. Appl. Phys. Lett. 2010, 96, 2506. [CrossRef]

53. She, Y.; Zheng, Q.; Li, L.; Zhang, Y.; Chen, C.; Zheng, Y.; Lin, X. Rare earth oxide modified $\mathrm{CuO} / \mathrm{CeO}_{2}$ catalysts for the water-gas shift reaction. Int. J. Hydrog Energy 2009, 34, 8929-8936. [CrossRef]

54. Tiwari, A.; Bhosle, V.M.; Ramachandran, S.; Sudhakar, N.; Narayan, J.; Budak, S.; Gupta, A. Ferromagnetism in $\mathrm{Co}$ doped $\mathrm{CeO}_{2}$ : Observation of a giant magnetic moment with a high Curie temperature. Appl. Phys. Lett. 2006, 88, 142511. [CrossRef]

55. Thurber, A.; Reddy, K.M.; Shutthanandan, V.; Engelhard, M.H.; Wang, C.; Hays, J.; Punnoose, A. Ferromagnetism in chemically synthesized $\mathrm{CeO}_{2}$ nanoparticles by Ni doping. Phys. Rev. B 2007, 76, 165206. [CrossRef]

56. Sharma, S.; Thakur, P.; Kumar, S.; Shukla, D.K.; Brookes, N.B.; Lee, C.G.; Pirota, K.R.; Koo, B.H.; Knobel, M. Room temperature ferromagnetism in Fe-doped $\mathrm{CeO}_{2}$ thin films grown on $\mathrm{LaAlO}_{3}(001)$. Thin Solid Films 2010, 519, 410-413. [CrossRef]

57. Ho, C.; Yu, J.C.; Kwong, T.; Mak, A.C.; Lai, S. Morphology-controllable synthesis of mesoporous $\mathrm{CeO}_{2}$ nano-and microstructures. Chem. Mater. 2005, 17, 4514-4522. [CrossRef]

58. Chen, H.-I.; Chang, H.-Y. Synthesis of nanocrystalline cerium oxide particles by the precipitation method. Ceram. Int. 2005, 31, 795-802. [CrossRef]

59. Masui, T.; Fujiwara, K.; Machida, K.-I.; Adachi, G.-Y.; Sakata, T.; Mori, H. Characterization of cerium (IV) oxide ultrafine particles prepared using reversed micelles. Chem. Mater. 1997, 9, 2197-2204. [CrossRef]

60. Patsalas, P.; Logothetidis, S.; Sygellou, L.; Kennou, S. Structure-dependent electronic properties of nanocrystalline cerium oxide films. Phys. Rev. B 2003, 68, 035104. [CrossRef] 
61. Tsunekawa, S.; Sahara, R.; Kawazoe, Y.; Kasuya, A. Blueshifts in the ultraviolet absorption spectra of cerium oxide nanocrystallites. J. Appl. Phys. 2003, 94, 3654-3656. [CrossRef]

62. Vinu, R.; Akki, S.U.; Madras, G. Investigation of dye functional group on the photocatalytic degradation of dyes by nano-TiO 2 . J. Hazard. Mater. 2010, 176, 765-773. [CrossRef] [PubMed]

63. Torres-Martínez, L.M.; Ruiz-Gómez, M.A.; Figueroa-Torres, M.Z.; Juárez-Ramírez, I.; Moctezuma, E. $\mathrm{Sm}_{2} \mathrm{FeTaO}_{7}$ photocatalyst for degradation of indigo carmine dye under solar light irradiation. Int. J. Photoenergy 2012, 2012, 939608. [CrossRef]

(c) 2016 by the authors; licensee MDPI, Basel, Switzerland. This article is an open access article distributed under the terms and conditions of the Creative Commons Attribution (CC-BY) license (http://creativecommons.org/licenses/by/4.0/). 